\title{
Burd Gol Granite Massif as a product of the Late Cambrian post- -orogenic magmatism in the SE part of the Lake Zone, Gobi Altay, SW Mongolia
}

\author{
Kristýna HRDLIČKOVÁ ${ }^{*}$, Axel GERDES², Helena GILÍKOVÁ', Dash BAT-ULZII , Pavel HANŽL' \\ ${ }^{1}$ Czech Geological Survey, Klárov 3, 11821 Prague 1, Czech Republic; kristyna.hrdlickova@geology.cz \\ ${ }^{2}$ Institut für Geowissenschaften, J. W. Goethe Universität, Altenhöferallee 1, 60438 Frankfurt am Main, Germany \\ ${ }^{3}$ Department of Geology and Mineralogy, Mongolian University of Science and Technology, Ulaanbaatar-46/520, Mongolia \\ * Corresponding author
}

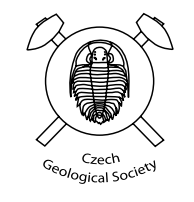

\begin{abstract}
Intrusion of the Cambrian Burd Gol Granite Massif into the Proterozoic metamorphic rocks of the Zamtyn Nuruu and molasse-like sediments of the Boomyn Khudag Fm. culminated the collisional events of the Caledonian evolution in the SE part of the Lake Zone, Gobi Altay, SW Mongolia. The monotonous leucogranites of the Burd Gol Massif have a high-K calc-alkaline, subaluminous to slightly peraluminous geochemical signature with an intermediate initial $\mathrm{Sr}$ ratio $\left({ }^{87} \mathrm{Sr}^{186} \mathrm{Sr}_{510}=0.7064\right)$ and rather unradiogenic $\mathrm{Nd}\left(\varepsilon_{N d}^{510}=-1.5\right.$ and -0.2$)$. The laser ablation ICP-MS U-Th- $\mathrm{Pb}$ radiometric dating of monazites and zircons from these rocks yields intrusive ages between $506.4 \pm 5.4$ and $513.4 \pm$ 4.3 Ma $(2 \sigma)$. The final stage of magmatic activity is documented by the Ar-Ar dating of muscovite from a pegmatite dyke at $485.1 \pm 3.2 \mathrm{Ma}$. The granites intruded and thermally influenced the terrestrial clastic sediments of the Boomyn Khudag Formation, whereby the thermal metamorphism of sediments was characterized by a muscovite growth. These new data argue against the previously assumed Permian age of the Burd Gol Massif and the Lower-Middle Devonian age of the Boomyn Khudag sedimentary formation and illustrates the terrestrial evolution in this part of the Lake Zone during the Cambrian.
\end{abstract}

Keywords: Lake Zone, Burd Gol granite Massif, geochemistry, radiometric dating, Lower Palaeozoic continental sediments, Gobi Altay Received: 22 September 2010; accepted: 8 December 2010; handling editor: M. Štemprok

The online version of this article (doi: 10.3190/jgeosci.081) contains supplementary electronic material.

\section{Introduction}

The Central Asian Orogenic Belt (CAOB) defined originally by Mossakovsky et al. (1993) and subsequently studied by number of authors (e.g. Sengör et al. 1993; Dergunov 2001; Jahn et al. 2004; Yakubchuk et al. 2005; Kröner et al. 2007; Windley et al. 2007) originated between the Siberian, Tarim and Sino-Korean blocks. The accretion including a number of arcs, microcontinents and obducted oceanic crust gave rise to a complicated collage of lithotectonic units forming one of the largest accretionary orogenic belts in the world (Jahn 2004; Yuan et al. 2007) penetrated by numerous granitic intrusions of ages ranging widely from Neoproterozoic to Cretaceous (Jahn et al. 2000). Although the number of radiometric and isotopic data has increased rapidly during the last decade (e.g. Kozakov et al. 1999, 2001, 2008; Jahn et al. 2004; Kröner et al. 2001, 2007; Jian et al. 2010 and others), the further well-focussed study of intrusive bodies can clearly shed new light onto continental growth in this part of Mongolia.

This paper describes the late evolutionary stage of the Cadomian orogeny in the Lake Zone of the CAOB based on new geochemical and radiometric data on a small
Burd Gol Granite Massif and sedimentological characteristics of terrigenous siliciclastic sediments in its roof.

\section{Geological setting}

\subsection{Regional overview}

The Mongolian part of the CAOB is divided into the northern and southern domains, separated by the suture of Main Mongolian Lineament (Tomurtogoo 1997) (Fig. 1). The two were classified by Marinov et al. (1973) as Caledonian and Hercynian orogens, respectively. Badarch et al. (2002) postulated that the earlier, Proterozoic and Lower Palaeozoic rocks occur in the north and the later, Lower to Upper Palaeozoic in the south. In the area of junction of the Mongolian and Gobi Altay ranges, these domains are represented by the Lake Zone and Gobi Altay terranes (Fig. 1), respectively.

The Lake Zone Terrane is built by island arc volcanic, volcanosedimentary and sedimentary rocks with ophiolitic remnants and local granitic and granosyenitic intrusions (Badarch et al. 2002). The island arc was formed between Cambrian and Ordovician on the Neoproterozoic 

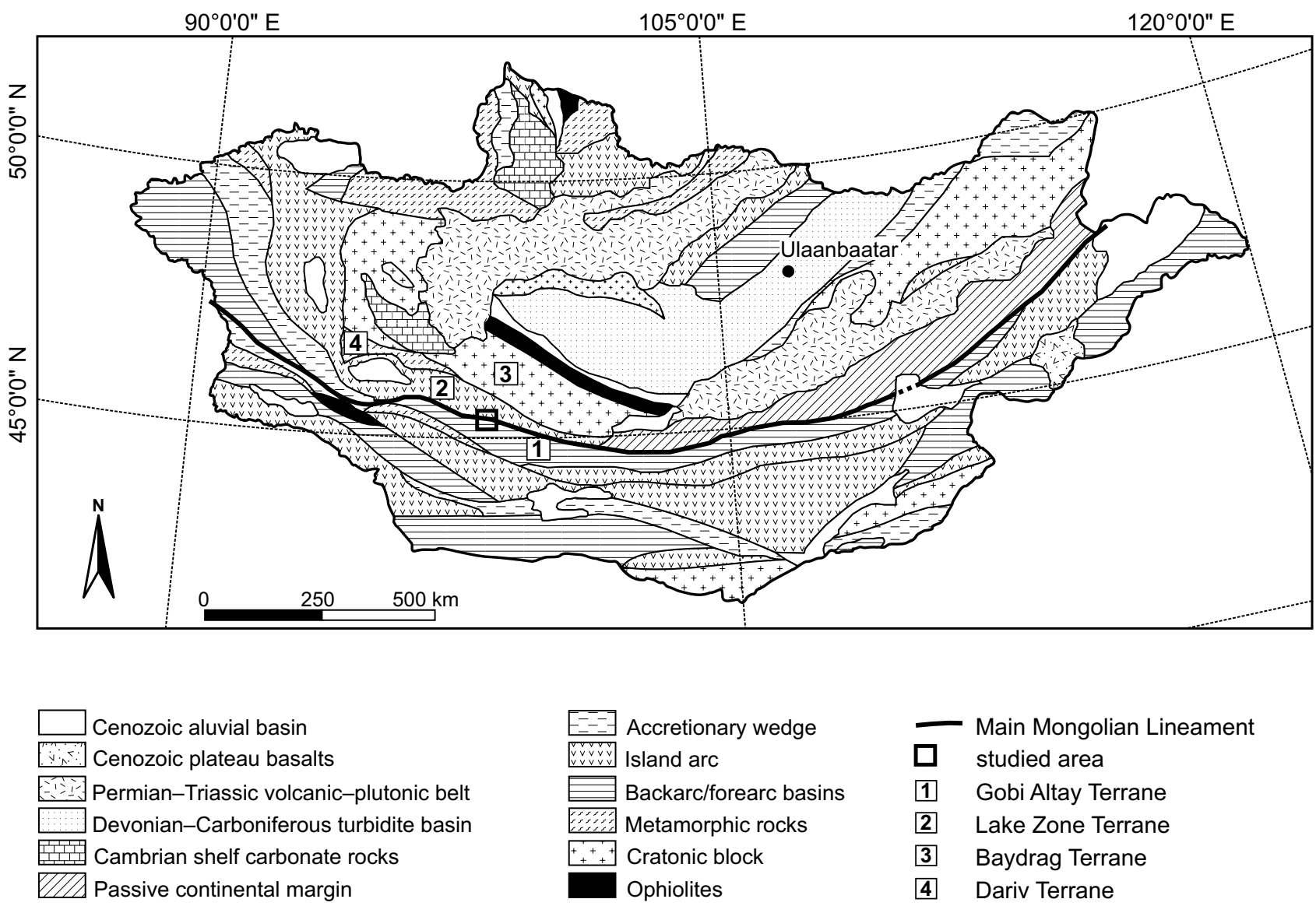

Fig. 1 Simplified tectonostratigraphic map of Mongolia (according to Badarch et al. 2002) with the position of the studied area and terranes mentioned in text.

oceanic crust. Subsequently, after the main accretion, the area of the Lake Zone Terrane was overlain by Silurian and Devonian marine and Permian to Mesozoic clastic sediments, and intruded by the Ordovician, Devonian and Permian volcanic and plutonic rock sequences. The Gobi Altay Zone is interpreted to having originated in a backarc/forearc basin (Badarch et al. 2002). Lower Paleozoic metamorphic complexes intruded by Variscan granite plutons are documented in this part of the Gobi Altay Zone (Economos et al. 2008; Hrdličková et al. 2008).

The studied area is situated at the western tip of the Gobi Altay Range in SW Mongolia, approximately 740 $\mathrm{km} \mathrm{SW}$ of Ulaanbaatar and $20 \mathrm{~km}$ E of Chandman village, north of the Chandman Khayrkhan Uul Mt., along the river Burd Gol (Fig. 1). Geologically, the Burd Gol Granite Massif belongs to the southernmost part of the Lake Zone, close to the boundary between the Lake Zone and Gobi Altay terranes. The Lake Zone in this region is composed of a tectonic collage of deep-water sediments with ophiolite remnants of the Khan Taishir Formation (Markova 1975; Zonenshain and Kuzmin 1978), a slightly metamorphosed volcanosedimentary complex with silicified limestones of Neoproterozoic to Cambrian age (Markova 1975; Hanžl et al. 2007a) and by metamorphic complex of the Zamtyn Nuruu Mt. Range. The metamorphic rocks of the Zamtyn Nuruu are supposed to be of Neoproterozoic age (Rauzer et al. 1987; Kröner et al. 2010). The metamorphic complex is covered by terrestrial siliciclastic sediments of the Boomyn Khudag Formation (newly defined as being of Early Palaeozoic age) and Permian volcaniclastic rocks (Rauzer et al. 1987; Buriánková and Hanžl eds 2007; Hanžl ed. 2007a; Hanžl ed. 2007b) (Fig. 2).

\subsection{Geology of the Burd Gol Granite Massif}

The Burd Gol Granite Massif forms a suboval body with outcrop diameter of $10-12 \mathrm{~km}$. The southern boundary is tectonic and corresponds with the Chandman Rupture of the Bogd Fault (Baljinnyam et al. 1993) separating the Lake Zone and Gobi Altay terranes here. Other contacts are intrusive and tectonically reworked in most places. The boundaries are partly covered by Quaternary sediments in a flat terrain.

The Neoproterozoic Zamtyn Nuruu Crystalline Complex is exposed north of the Burd Gol Granite Massif. 


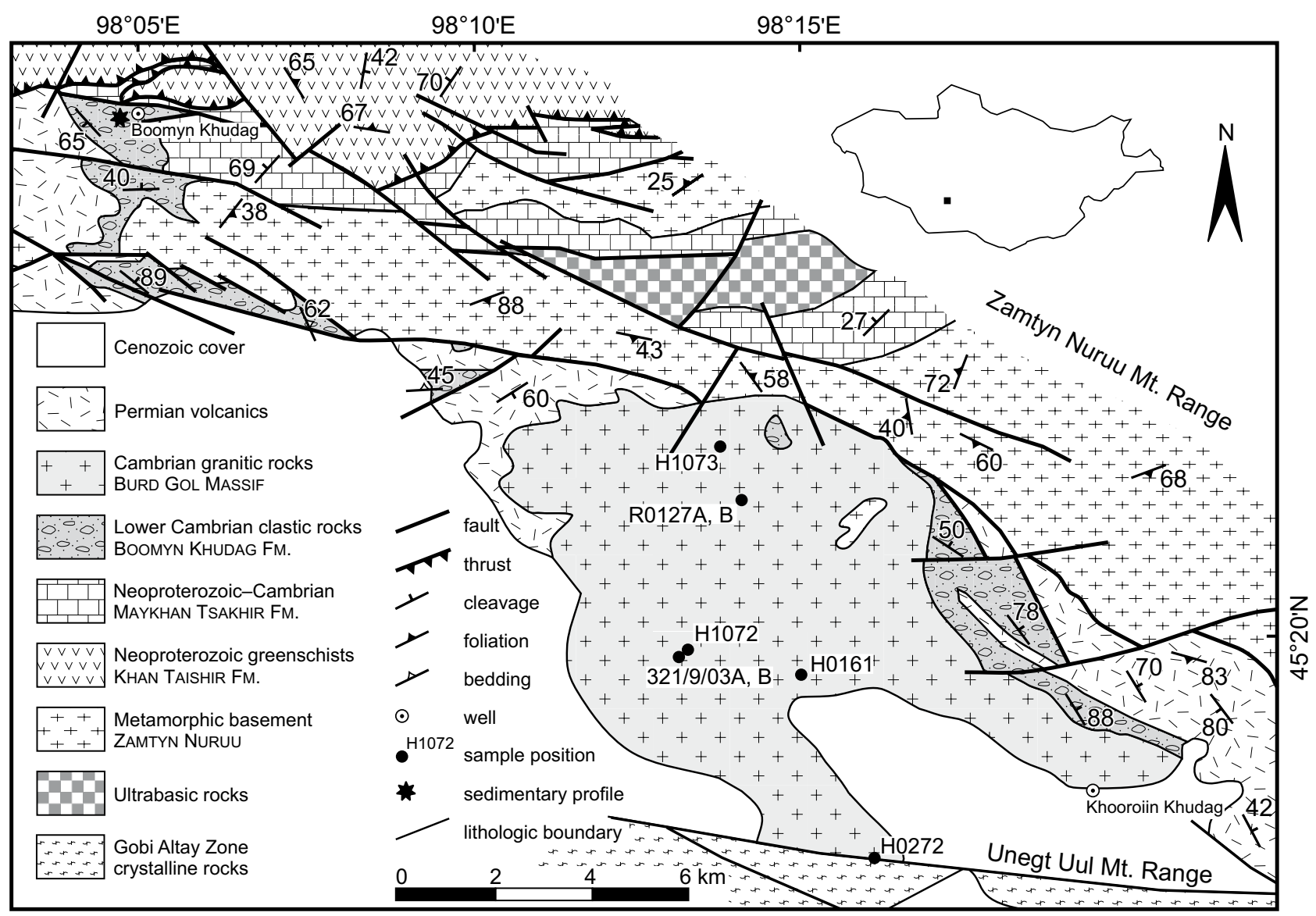

Fig. 2 Geological sketch map of the studied area of the Burd Gol Granite Massif with sample locations.

This high-grade metamorphic unit is composed of the alternation of various ortho- and paragneisses with intercalations of marbles, amphibolites and micaschists and it is intruded by number of small magmatic bodies (Hanžl ed. 2007a; Buriánková and Hanžl eds 2007; Lehmann et al. 2010). Enclaves of amphibolites and paragneisses ranging to mica schists common in the northern part of pluton provide an evidence for original intrusive relations between Zamtyn Nuruu Crystalline Complex and Burd Gol Massif, subsequently reworked by younger faults.

Also the contacts with sandstones of the Boomyn Khudag Formation are tectonically reworked, but thermally metamorphosed sandstones were found in large septa within the pluton. Silicification and occurrences of $\mathrm{Cu}$ mineralization in sandstones and siltstones at its exocontact indicate a hydrothermal activity.

Permian volcanic rocks with dacites, rhyolitic lapilli tuffs and ignimbrites, prevailing over rare basalt lavas and lenses of conglomerates, sandstones and siltstones, cover all the above-mentioned rocks. The remains of flora with prevailing Rufloria sp. found near the western margin of the pluton indicate an age close to the Early-Late Permian boundary (Hanžl et al. 2007a). The position of the Permian rocks is also influenced by younger strikeslip movements and they are reoriented, together with sediments of the Boomyn Khudag Formation, to asymmetric tails along the Burd Gol Granite Massif.

\subsection{Previous age determinations}

The metamorphic age of Zamtyn Nuruu orthogneiss was determined by Gerdes and Buriánková (2007) as Early Cambrian $(524+17 /-13 \mathrm{Ma}$, U-Th-Pb LA-ICPMS zircon dating). Somewhat lower ages of $517 \pm 5 \mathrm{Ma}$ were provided by the U-Th-Pb LA-ICP-MS zircon dating of small granite and diorite bodies which intruded this metamorphic complex (Gerdes and Buriánková 2007).

The detailed studies by Kröner et al. (2010) provided a number of new geochronological data interpreted in a broader geological context. Their dating indicates Mesoproterozoic protolith ages for the Zamtyn Nuruu crystalline basement (inheritance in granitic gneiss $950 \pm$ $16 \mathrm{Ma})$. This corresponds well to the unpublished zircon radiometric data of Gerdes and Buriánková (2007) yielding $940 \pm 44 \mathrm{Ma}$ in coarse-grained orthogneiss. 


\section{Analytical methods}

Eight samples were studied and analysed using various geochemical and geochronological methods. List and localization of samples is presented in Tab. 1.

Whole-rock chemical analyses were carried out at the Acme Analytical Laboratories, Vancouver, Canada. Major element contents were determined using ICP-OES, following a lithium metaborate/tetraborate fusion and dilute nitric digestion. Loss on ignition (LOI) was calculated by weight difference after ignition at $1000{ }^{\circ} \mathrm{C}$. The rare earth and most remaining trace elements were analysed by INAA and ICP-MS. Whole-rock analyses were interpreted by the GCDkit software (Janoušek et al. 2006).

$\mathrm{The} \mathrm{Sr}-\mathrm{Nd}$ isotope analyses were performed in the Radiogenic Isotope Laboratory of the Czech Geological Survey in Prague on Finnigan MAT 262 thermal ionization mass spectrometer in dynamic mode using a double Re filament assembly. Long-time averages for the Sr NBS 987 and $\mathrm{Nd} \mathrm{La}$ Jolla reference materials were 0.710246 $(2 \sigma=0.000026, \mathrm{n}=25)$ and $0.511852(2 \sigma=0.000014$, $\mathrm{n}=23$ ), respectively. The decay constants applied to age-correct the isotopic ratios are from Steiger and Jäger (1977) (Sr) and Lugmair and Marti (1978) (Nd). The $\left(\varepsilon_{N d}^{i}\right)$ values were obtained using Bulk Earth parameters of Jacobsen and Wasserburg (1980).

Zircon and monazite were analyzed for $\mathrm{U}$, Th and $\mathrm{Pb}$ isotopic compositions by Laser Ablation Inductive Coupled Plasma Mass Spectrometry (LA-ICP-MS) technique at the Institute of Geosciences, Johann Wolfgang Goethe University Frankfurt, using a Thermo-Finnigan Element II sector field ICP-MS coupled to a New Wave UP213 ultraviolet laser system. For zircon, the laser spot-sizes varied from 20 to $40 \mu \mathrm{m}$ and were placed based on the SEM and CL images of the individual grains. The typical depth of the ablation crater was $\sim 20 \mu \mathrm{m}$. Monazite was analyzed with 16 to $30 \mu \mathrm{m}$ spot size. In both cases, the data were acquired in peak jumping mode over 900 mass scans during 20s background measurement followed by $32 \mathrm{~s}$ sample ablation. For further details on analytical protocol and data processing see Gerdes and Zeh (2006).

Independent age dating was performed by measuring the ${ }^{40} \mathrm{Ar}{ }^{*} /{ }^{39} \mathrm{Ar}$ isotopic ratio in muscovite at the Central European Ar-Laboratory (CEAL) in the Geological Institute of Slovak Academy of Science, Bratislava, equipped with VG 5400 Noble Gas Mass Spectrometer and special, in house built Ar gas extraction line. Samples had to be irradiated with fast neutrons/neutron capture and proton emission reaction in Nuclear Research Institute, Řež, Czech Republic and the Ar-Ar data were subsequently acquired during step-wise high-frequency generator heating with electronic method of gas detection. Step-wise progressive outgassing of the sample was done mostly in 8-10 temperature steps from 610 to $1250^{\circ} \mathrm{C}$.

Each separate value on the $\mathrm{Y}$ axis in the age plot is corresponding to a single degassing of the sample at the given temperature. According to Dickin (1997) each Ar gas fraction is plotted as a bar, whose length represents the volume as a fraction of the total gas $-{ }^{39} \mathrm{Ar}$ released from the sample and whose value is the corrected ${ }^{40} \mathrm{Ar} /{ }^{39} \mathrm{Ar}$ isotopic ratio. The identification of the "plateau" or "mean" age is very important for determination of reliable age - it corresponds with choice or extraction of a series of adjacent steps, which together comprise more than $50 \%$ of the total Ar released.

The monazites were examined in detail using a CAMECA SX 100 electron microprobe in the Joint Laboratory of Electron Microscopy and Microanalysis of the Masaryk University and Czech Geological Survey (Brno, Czech Republic). Operating conditions were $15 \mathrm{kV}$ an accelerating voltage, a beam current of $80 \mathrm{nA}$ and a beam diameter of $<1 \mathrm{~mm}$ for monazite and $5-10 \mathrm{~mm}$ for monazite alteration products. Peak counting times were $20 \mathrm{~s}$ for major elements and 30-60 s for most of minor elements. Uranium was determined on the $\mathrm{U}_{\beta}$ line (counting time $60 \mathrm{~s}$, detection limit $270 \mathrm{ppm}$ ), thorium on the $\mathrm{Th} \mathrm{M}_{\alpha}$ (counting time $40 \mathrm{~s}$, detection limit 250 ppm) and lead on the $\mathrm{Pb} \mathrm{M}$ line (counting time $240 \mathrm{~s}$, detection limit $130 \mathrm{ppm}$ ). The following standards were used: $\mathrm{U}-\mathrm{U}, \mathrm{Pb}-\mathrm{PbSe}, \mathrm{Th}-\mathrm{ThO}_{2}, \mathrm{P}$ - apatite, $\mathrm{Y}-\mathrm{YAG}$, $\mathrm{La}-\mathrm{LaB}_{6}, \mathrm{Ce}-\mathrm{CeAl}_{2}, \mathrm{Pr}-\mathrm{PrF}_{3}, \mathrm{Nd}-\mathrm{NdF}_{3}, \mathrm{Gd}-\mathrm{GdF}_{3}$, $\mathrm{Sm}-\mathrm{SmF}_{3}, \mathrm{Dy}-\mathrm{DyP}_{5} \mathrm{O}_{14}, \mathrm{Er}-\mathrm{YErAG}, \mathrm{Al}$ - almandine, $\mathrm{Si}$ - andradite, $\mathrm{Ca}$ - andradite, $\mathrm{Fe}$ - andradite, $\mathrm{Mn}$ - rhodonite, $\mathrm{V}$ - vanadinite, $\mathrm{S}$ - baryte. Data were reduced using the PAP matrix correction routine (Pouchou and Pichoir 1985).

Microprobe monazite analyses were used for monazite dating (CHIME - chemical Th-U-total $\mathrm{Pb}$ isochron method) assuming that all $\mathrm{Pb}$ is radiogenic (Parrish 1990). The monazite age was calculated with the method of Montel et al. (1996). Lead content was additionally manually corrected for $\mathrm{Y}_{\gamma 2}, \mathrm{Th}_{\mathrm{\zeta}_{1}}$ and $\mathrm{Th}_{\zeta 2}$ overlap on $\mathrm{Pb} \mathrm{M}_{\alpha}$. Besides mentioned overlaps, the analytical precision of $\mathrm{Pb}$ on the $\mathrm{M}_{\alpha}$ line is higher than on $\mathrm{M}_{\beta}$ line where

Tab. 1 Location of the granite samples from the Burd Gol Granite Massif and sedimentary profile

\begin{tabular}{lcccccccc}
\hline sample & H0161 & H0272 & H1072 & H1073 & R0127A, B & 321/9/03A & $\begin{array}{c}\text { 321/9/03B } \\
\text { sedimentary } \\
\text { profile }\end{array}$ \\
\hline N coordinate & 45.32711 & 45.29054 & 45.33135 & 45.36633 & 45.35967 & 45.33128 & 45.33128 & 45.42594 \\
E coordinate & 98.24071 & 98.27132 & 98.2185 & 98.22707 & 98.22949 & 98.21835 & 98.21835 & 98.07233 \\
\hline
\end{tabular}


no significant overlap occurs. The monazite structure is strongly resistant to metamictization and the loss of $\mathrm{Pb}$ as a consequence of accumulation of radiation damage by $\alpha$-particles is not likely (Meldrum et al. 1997). The homogeneity of the data file was verified by the construction of the $\mathrm{Th}^{*}-\mathrm{Pb}$ plot ( $\mathrm{Th}^{*}$ equal to the theoretical $\mathrm{Th}$ content which would produced the measured $\mathrm{Pb}$ for the calculated age.)

\section{Characteristics of the Burd Gol Massif}

The sub-oval body of the Burd Gol Massif is exposed in the shallow valley of the Burd Gol river N of the Chandman Khayrkhan Uul Mt. The massif is lithologically homogeneous, being composed of leucocratic granite penetrated by numerous dykes of subvolcanic basalts, andesites and dacites and frequent quartz veins. Aplite and pegmatite dykes are exceptional. No significant effects of ductile or semi-ductile deformation were found in the pluton, which suggests a post-orogenic evolution. The wrapping of the structural trends (Hanžl ed. 2007c) of the Boomyn Khudag Formation around the contacts with the Burd Gol Granite Massif and faulted boundary with adjacent units indicates a rotation of the granitic body due to later post-magmatic strike-slip movements. The southern part of the massif incorporated to the structure of the Bogd Fault was deformed and locally mylonitized in the tectonic mélange related to the fault (Valtr and Hanžl 2008).

\subsection{Petrography}

The granites of the Burd Gol Granite Massif are monotonous, homogenous leucocratic (muscovite-) biotite granites, fine to medium-grained, pale grey or reddish in colour. The main minerals are quartz, perthitic K-feldspar and plagioclase of albite to oligoclase composition. Biotite and locally muscovite are subordinate. Euhedral to subhedral plagioclases with oscillatory zoning are intensely sericitized in the cores. Subhedral alkali feldspar commonly contains microcline lamellae. Kaolinization of feldspars is relatively common. Small biotite flakes frequently enclosed in feldspars are partly replaced by chlorite. Apatite, monazite and zircon occur as typical accessory phases.

The analysed samples R0127A, H1072 and H1073 are all very similar medium-grained leucocratic granites with biotite and euhedral feldspars, whereby plagioclase of oligoclase composition slightly prevails over K-feldspar. Quartz grains show slight undulatory extinction. R0127B contains muscovite flakes in addition.

The samples 331/6/03A and 321/6/03B are leucocratic medium-grained granites to granodiorites with phaneritic texture. The mineral assemblage includes quartz, feld- spars of albite to oligoclase composition and sporadic muscovite. Titanite and monazite are accessoric.

The sample H0272, which represents a deformed granite from the tectonic mélange at the southern margin of the massif, differs slightly from the other samples. It has distinct planar fabric defined by biotite, grading locally to banding, and a markedly higher mica content, in particular of biotite. The crushed titanite is an abundant accessory phase. The differences from other samples are noticeable in chemical and isotopic characteristics, suggesting that this sample may not have originally belonged to the Burd Gol Granite Massif. In any case, it was strongly deformed and altered during its incorporation into the tectonic zone of the Bogd Fault.

The massif contains scarce pegmatite and aplite dykes with thickness up to 1-2 metres. One of them (H0161) was sampled and its muscovite subjected to the Ar-Ar dating. It was a coarse-grained quartzo-feldspathic rock with muscovite flakes up to $2 \mathrm{~cm}$ in size.

\subsection{Whole-rock geochemistry}

The presented analytical data represent lithogeochemical samples collected during the geological survey of the Zamtyn Nuruu area (Hanžl and Aichler eds 2007). The list of samples and major-element data are in Tab. 2, trace-elements in Tab. 3.

Intrusive rocks of the Burd Gol Granite Massif can be classified as granite in TAS diagram (Cox et al. 1979). Except for the sample H0272, which falls into field of

Tab. 2 Whole-rock major-element analyses (wt. \%)

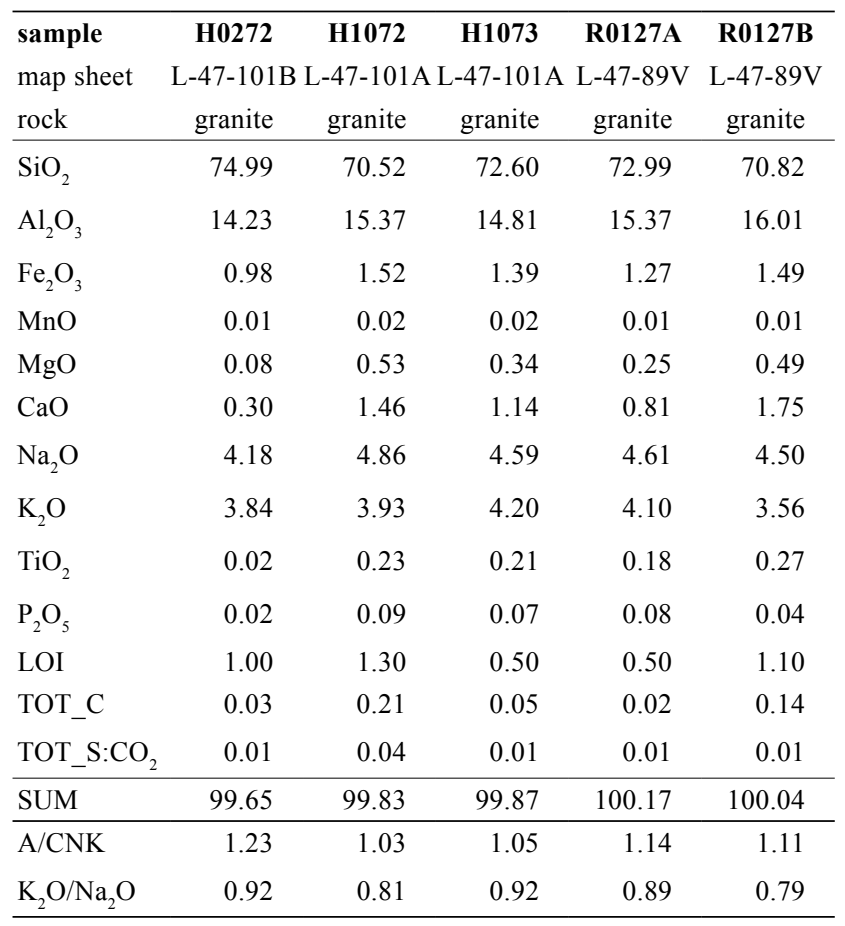



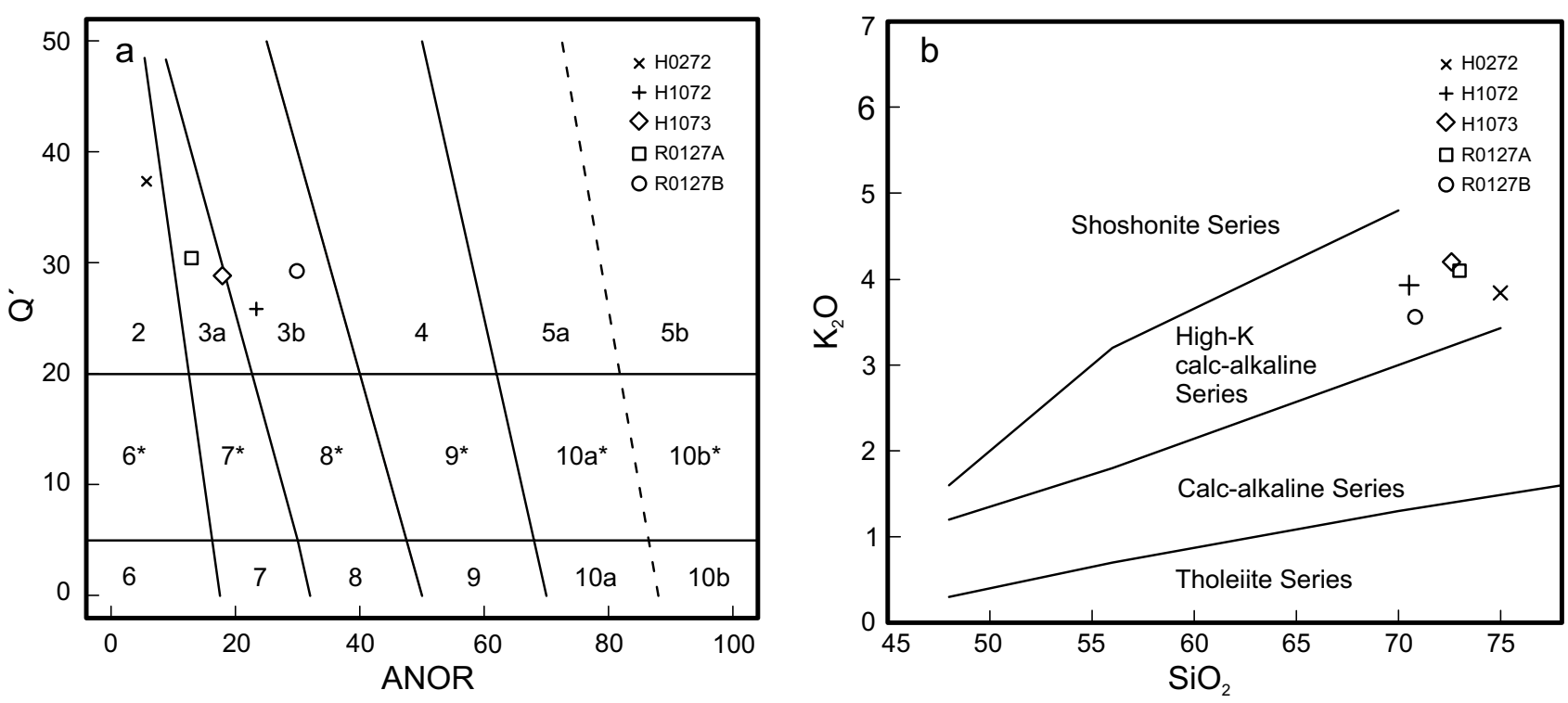

Fig. 3 Geochemical classification of granites of the Burd Gol Granite Massif. a - Q'-ANOR diagram of Streckeisen and Le Maitre (1979) based on the Improved Granite Mesonorm (Mielke and Winkler 1979): 2 - alkali feldspar granite, 3 - granite, 4 - granodiorite, 5 - tonalite, $6^{*}-$ quartzalkali feldspar syenite, $7^{*}$ - quartz syenite, $8^{*}$ - quartz monzonite, $9^{*}$ - quartz monzonite/quartz monzogabbro, $10^{*}-$ quartz diorite/quartz gabb-

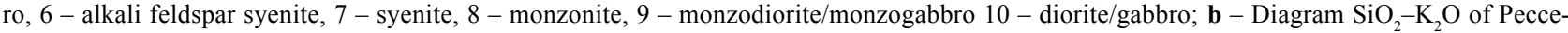
rillo and Taylor (1976).

alkaline granite, the rocks are classified as granites in $\mathrm{Q}^{\prime}-$ ANOR diagram (Streckeisen and Le Maitre 1979) based on Improved Granite Mesonorm (Mielke and Winkler 1979; Fig. 3a). Granites show little compositional variation (except for H0272; Tabs 2-3), silica contents range from 71 to $75 \mathrm{wt}$ \%. They are high-K calc-alkaline $\left(\mathrm{K}_{2} \mathrm{O}\right.$ $=3.6-4.2$ wt. $\left.\% ; \mathrm{K}_{2} \mathrm{O} / \mathrm{Na}_{2} \mathrm{O}=0.8-0.9\right)$ (Fig. 3b) and have subaluminous to slightly peraluminous character $(\mathrm{A} / \mathrm{CNK}$ $=1.05-1.14)$. The $\mathrm{Rb} / \mathrm{Sr}$ ratios $(0.09-0.13)$ with $\mathrm{Ti}, \mathrm{P}$ and REE contents are low $\left(\mathrm{TiO}_{2}=0.18-0.27\right.$ wt. $\% ; \mathrm{P}_{2} \mathrm{O}_{5}=$ $0.04-0.09$ wt. $\%, \Sigma$ REE $=87-252 \mathrm{ppm})$. Only the sample $\mathrm{H} 0272$ is compositionally different $\left(\mathrm{Rb} / \mathrm{Sr}=6.05, \mathrm{TiO}_{2}=\right.$ 0.02 wt. $\%, \mathrm{P}_{2} \mathrm{O}_{5}=0.02$ wt. $\%$; $\Sigma \mathrm{REE}=62 \mathrm{ppm}$ ).

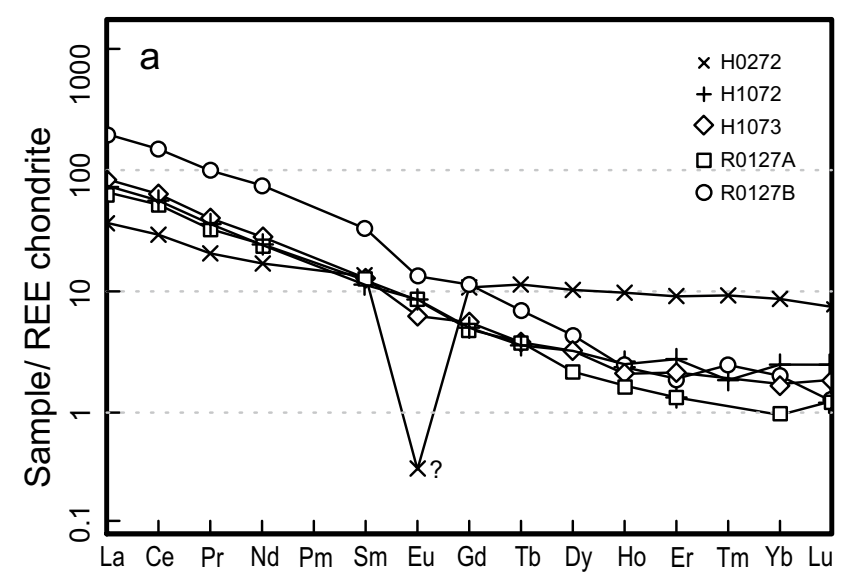

Chondrite-normalized (Boynton 1984) REE patterns are relatively well fractionated $\left(\mathrm{La}_{\mathrm{N}} / \mathrm{Yb}_{\mathrm{N}}=30-99 ; \mathrm{La}_{\mathrm{N}} /\right.$ $\left.\mathrm{Sm}_{\mathrm{N}}=5.3-6.6\right)$ with negligible to slight negative $\mathrm{Eu}$ anomaly $\left(\mathrm{Eu}^{*} / \mathrm{Eu}^{*}=0.7-1.1\right)$ (Fig. 4a). The pattern for the sample $\mathrm{H} 0272$ is different $\left(\mathrm{La}_{\mathrm{N}} / \mathrm{Yb}_{\mathrm{N}}=4 ; \mathrm{La}_{\mathrm{N}} / \mathrm{Sm}_{\mathrm{N}}=\right.$ 2.8 ), also by having a profound Eu negative anomaly with the $\mathrm{Eu}$ contents below the detection limit $\left(\mathrm{Eu} / \mathrm{Eu}^{*}\right.$ less than 0.06). The NMORB-normalized spider plot (Sun and McDonough 1989) displays a marked depletion in $\mathrm{Nb}, \mathrm{Ta}$, $\mathrm{Ti}, \mathrm{P}$ while $\mathrm{K}, \mathrm{Pb}, \mathrm{Nd}$ and $\mathrm{Sr}$ show a slight enrichment. In addition the sample $\mathrm{H} 0272$ is strongly depleted in Ba, Sr and Ti (Fig. 4b).

\subsection{Isotope geochemistry}

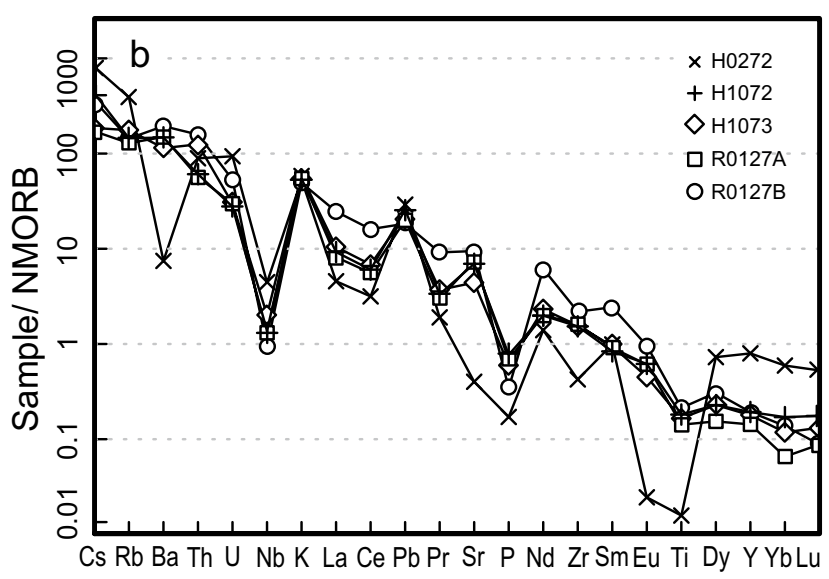

Fig. 4 Trace-element characteristic of the granites of the Burd Gol Massif. a - Chondrite-normalized (Boynton 1984) REE patterns; question mark indicates an Eu value below detection limit (which is plotted); b - NMORB normalized trace-element patterns according Sun and Mc Donough (1989). 
Tab. 3 Trace-element analyses (ppm, Au in ppb)

\begin{tabular}{|c|c|c|c|c|c|}
\hline $\begin{array}{l}\text { sample } \\
\text { rock }\end{array}$ & $\begin{array}{l}\text { H0272 } \\
\text { granite }\end{array}$ & $\begin{array}{l}\text { H1072 } \\
\text { granite }\end{array}$ & $\begin{array}{l}\text { H1073 } \\
\text { granite }\end{array}$ & $\begin{array}{c}\text { R0127A } \\
\text { granite }\end{array}$ & $\begin{array}{c}\text { R0127B } \\
\text { granite }\end{array}$ \\
\hline$\overline{\mathrm{Ag}}$ & $<0.1$ & $<0.1$ & $<0.1$ & $<0.1$ & $<0.1$ \\
\hline As & 2.7 & 0.5 & $<0.5$ & 0.8 & 1.1 \\
\hline $\mathrm{Au}$ & 1.1 & 0.6 & 1.4 & $<0.5$ & 0.7 \\
\hline $\mathrm{Ba}$ & 47.0 & 927.7 & 719.1 & 941.5 & 1222.5 \\
\hline $\mathrm{Be}$ & 3.0 & 1.0 & 1.0 & 2.0 & 1.0 \\
\hline $\mathrm{Bi}$ & 0.6 & 0.1 & $<0.1$ & $<0.1$ & 0.1 \\
\hline $\mathrm{Cd}$ & $<0.1$ & 0.1 & $<0.1$ & $<0.1$ & $<0.1$ \\
\hline Co & 0.8 & 2.1 & 2.0 & 1.9 & 2.6 \\
\hline Cs & 5.7 & 3.0 & 1.3 & 1.2 & 2.5 \\
\hline $\mathrm{Cu}$ & 8.4 & 15.5 & 15.1 & 8.3 & 4.1 \\
\hline $\mathrm{Ga}$ & 21.2 & 17.8 & 19.8 & 21.7 & 19.7 \\
\hline $\mathrm{Hf}$ & 1.5 & 2.9 & 3.6 & 3.0 & 4.5 \\
\hline $\mathrm{Hg}$ & 0.01 & 0.02 & 0.02 & $<0.01$ & $<0.01$ \\
\hline Mo & 0.2 & 0.5 & 0.2 & 0.4 & 0.3 \\
\hline $\mathrm{Nb}$ & 10.3 & 3.2 & 4.7 & 3.0 & 2.2 \\
\hline $\mathrm{Ni}$ & 1.9 & 2.8 & 2.5 & 3.2 & 4.3 \\
\hline $\mathrm{Pb}$ & 8.8 & 7.7 & 6.7 & 6.0 & 5.5 \\
\hline $\mathrm{Rb}$ & 218.3 & 81.2 & 98.6 & 72.1 & 80.6 \\
\hline $\mathrm{Sb}$ & $<0.1$ & $<0.1$ & $<0.1$ & 0.1 & $<0.1$ \\
\hline $\mathrm{Sn}$ & 4 & 3 & 2 & 1 & 2 \\
\hline $\mathrm{Sr}$ & 36.1 & 625.9 & 396.9 & 659.9 & 851.8 \\
\hline $\mathrm{Ta}$ & 1.1 & 0.3 & 0.7 & 0.2 & 0.2 \\
\hline Th & 10.7 & 7.3 & 15.0 & 6.8 & 19.0 \\
\hline $\mathrm{Tl}$ & 0.1 & 0.1 & $<0.1$ & $<0.1$ & 0.1 \\
\hline $\mathrm{U}$ & 4.4 & 1.3 & 1.4 & 1.4 & 2.5 \\
\hline V & $<5$ & 18 & 15 & 17 & 27 \\
\hline W & 1.3 & 1.8 & 0.9 & 0.4 & 0.3 \\
\hline $\mathrm{Zn}$ & 12 & 32 & 37 & 30 & 33 \\
\hline $\mathrm{Zr}$ & 31.4 & 113.3 & 115.7 & 119.1 & 161.6 \\
\hline $\mathrm{Se}$ & $<0.5$ & $<0.5$ & $<0.5$ & $<0.5$ & $<0.5$ \\
\hline $\mathrm{Sc}$ & 4.0 & 2.0 & 2.0 & 1.0 & 2.0 \\
\hline Y & 22.3 & 5.4 & 5.0 & 4.0 & 5.4 \\
\hline $\mathrm{La}$ & 11.4 & 23.1 & 26.1 & 20.4 & 61.5 \\
\hline $\mathrm{Ce}$ & 23.7 & 45.3 & 51.3 & 41.9 & 120.6 \\
\hline $\operatorname{Pr}$ & 2.51 & 4.39 & 4.89 & 3.98 & 12.09 \\
\hline $\mathrm{Nd}$ & 10.2 & 14.5 & 16.9 & 14.7 & 44.9 \\
\hline $\mathrm{Sm}$ & 2.6 & 2.2 & 2.5 & 2.4 & 6.4 \\
\hline $\mathrm{Eu}$ & $<0.05$ & 0.63 & 0.46 & 0.62 & 0.98 \\
\hline Gd & 2.79 & 1.30 & 1.44 & 1.26 & 2.95 \\
\hline $\mathrm{Tb}$ & 0.54 & 0.17 & 0.18 & 0.18 & 0.33 \\
\hline Dy & 3.31 & 1.04 & 1.04 & 0.70 & 1.40 \\
\hline Но & 0.70 & 0.18 & 0.15 & 0.12 & 0.17 \\
\hline $\mathrm{Er}$ & 1.91 & 0.58 & 0.45 & 0.28 & 0.40 \\
\hline $\mathrm{Tm}$ & 0.30 & 0.06 & $<0.05$ & $<0.05$ & 0.08 \\
\hline $\mathrm{Yb}$ & 1.81 & 0.52 & 0.36 & 0.20 & 0.42 \\
\hline $\mathrm{Lu}$ & 0.24 & 0.08 & 0.06 & 0.04 & 0.04 \\
\hline $\mathrm{Rb} / \mathrm{Sr}$ & 6.0 & 0.1 & 0.2 & 0.1 & 0.1 \\
\hline $\mathrm{K} / \mathrm{Rb}$ & 146.0 & 401.8 & 353.6 & 472.1 & 366.7 \\
\hline $\mathrm{Eu} / \mathrm{Eu}^{*}$ & $<0.06$ & 1.14 & 0.74 & 1.09 & 0.69 \\
\hline $\mathrm{La}_{\mathrm{N}} / \mathrm{Yb}_{\mathrm{N}}$ & 4.25 & 29.95 & 48.88 & 68.77 & 98.72 \\
\hline $\mathrm{La}_{\mathrm{N}} / \mathrm{Sm}_{\mathrm{N}}$ & 2.76 & 6.60 & 6.57 & 5.35 & 6.04 \\
\hline$C \mathrm{e}_{\mathrm{N}} / \mathrm{Yb}_{\mathrm{N}}$ & 3.39 & 22.53 & 36.86 & 54.19 & 74.27 \\
\hline$\Sigma$ REE & 62.0 & 94.1 & 105.8 & 86.8 & 252.3 \\
\hline
\end{tabular}

Two samples of the Burd Gol granites studied for $\mathrm{Sr}-$ $\mathrm{Nd}$ isotopic composition differ markedly from each other (Tab. 4). The high present-day $\mathrm{Sr}$ isotopic ratio in deformed medium-grained leucocratic granite $\mathrm{H} 0272$ $\left({ }^{87} \mathrm{Sr} /{ }^{86} \mathrm{Sr}=0.82951\right)$ reflects high $\mathrm{Rb} / \mathrm{Sr}$ ratio, obviously due to a high biotite content, and hence a significantly high time-integrated amount of radiogenic Sr. In such situation, it is difficult to calculate precisely the initial ${ }^{87} \mathrm{Sr} r{ }^{86} \mathrm{Sr}$ ratio, as it varies rapidly with age and also the influence of the $\mathrm{Sr}$ and $\mathrm{Rb}$ analytical uncertainty is significant. The initial ratio calculated for the presumed age $510 \mathrm{Ma}$ is strikingly low, but considering the associated error it may be realistic. It can be hardly useful for petrogenetic considerations; on the other hand, it gives another independent argument for the mid-Cambrian maximum age of the pluton.

The second sample R0127B is a leucocratic, two-mica granite from the central part of the Burd Gol Granite Massif. It has significantly less evolved strontium $\left({ }^{87} \mathrm{Sr} r{ }^{86} \mathrm{Sr}=\right.$ 0.7084 ), with initial value ${ }^{87} \mathrm{Sr} /{ }^{86} \mathrm{Sr}_{510}=0.70639$ (Tab. 4). This feature is corroborated by its slightly peraluminous nature and $\mathrm{Nd}$ isotope geochemistry.

Both the samples show a rather unradiogenic $\mathrm{Nd}$ $\left(\varepsilon_{N d}^{510}=-1.5\right.$ and -0.2$)$ with correspondingly high twostage $\mathrm{Nd}$ crustal residence ages $\left(\mathrm{T}_{N d}^{D M}=1.3\right.$ and $\left.1.2 \mathrm{Ga}\right)$ (Tab. 4).

\subsection{Geochronology}

A first hint on likely Cambrian age of the massif comes from the microprobe study of monazite-bearing granite samples from the central part of the Burd Gol Massif (321/6/03A and 321/6/03B). The electron microprobe monazite dating yielded ages between 536 and $497 \mathrm{Ma}$ (Tab. 5), in contrast to the work by Rauzer et al. (1987), who assumed a Permian age.

Two granite samples from the Burd Gol Granite Massif (H1072, H1073) were dated using U-Th- $\mathrm{Pb}$ zircon and monazite analysis (Tabs 6-7), pegmatite sample H0161 using $\mathrm{Ar}-\mathrm{Ar}$ method on muscovite.

Zircon grains from sample H1073 are clear to cloudy, colourless and mostly long-prismatic with a length of 150-200 $\mu \mathrm{m}$. The CL images (Fig. 5) display variable oscillatory zoning consistent with only one stage of zircon growth except for a single zircon grain. Zircons show a prismatic core, a dark oscillatory-zoned mantle and an uneven, 5-30 $\mu \mathrm{m}$ wide highly luminescent zone in between. Seventeen spots on 8 grains have been analysed (Tab. 7). The U contents vary from 40 to $c .700$ $\mathrm{ppm}$ yielding $\mathrm{Th} / \mathrm{U}$ ratios of 0.36 to 1.6. Fifteen spots define a discordia with upper intercept of $504 \pm 19 \mathrm{Ma}$ when forced through zero; nine of them are equivalent and concordant with a concordia age of $511 \pm 5 \mathrm{Ma}$. The latter datum is interpreted as the best estimate for the time 
Tab. 4 Radiogenic isotope data

\begin{tabular}{|c|c|c|c|c|c|c|c|c|c|c|c|c|c|c|c|c|}
\hline Sample & $\begin{array}{c}\text { Rock } \\
\text { type }\end{array}$ & $\begin{array}{l}\text { Age } \\
(\mathrm{Ma})^{1}\end{array}$ & $\begin{array}{c}\mathrm{Rb} \\
(\mathrm{ppm})\end{array}$ & $\begin{array}{c}\mathrm{Sr} \\
(\mathrm{ppm})\end{array}$ & ${ }^{87} \mathrm{Rb} /{ }^{86} \mathrm{Sr}$ & ${ }^{87} \mathrm{Sr} /{ }^{86} \mathrm{Sr}$ & 2 s.e. & ${ }^{2}\left({ }^{87} \mathrm{Sr} /{ }^{86} \mathrm{Sr}\right){ }_{\mathrm{i}}^{3}$ & $\begin{array}{c}\mathrm{Sm} \\
(\mathrm{ppm})\end{array}$ & $\begin{array}{c}\mathrm{Nd} \\
(\mathrm{ppm})\end{array}$ & ${ }^{147} \mathrm{Sm} /{ }^{144} \mathrm{~N}$ & & 2 s.e. & $\left({ }^{143} \mathrm{Nd} /{ }^{144} \mathrm{Nd}\right)_{\mathrm{i}}$ & $\varepsilon_{N d}^{510}$ & $\begin{array}{l}\mathrm{T}_{\mathrm{Nd}}^{\mathrm{DM} 4} \\
(\mathrm{Ga})\end{array}$ \\
\hline $\mathrm{H} 0272$ & granite & 510 & 218.3 & 36.1 & 17.7108 & 0.829507 & 12 & 0.70078 & 2.6 & 10.2 & 0.1541 & 0.512418 & 07 & 0.511903 & -1.5 & 1.30 \\
\hline R0127B & granite & 510 & 80.6 & 851.8 & 0.2739 & 0.708377 & 08 & 0.70639 & 6.4 & 44.9 & 0.0862 & 0.512260 & 07 & 0.511972 & -0.2 & 1.20 \\
\hline
\end{tabular}

assumed age based mainly on geological evidence;

2 standard errors of the mean for the isotopic measurement (the last two decimal digits);

isotopic ratios with subscript ' $i$ ' and epsilon Nd values $\left(\varepsilon_{N d}^{510}\right)$ were all age-corrected to the 'Assumed age';

two-stage Nd model ages (Ga) calculated using parameters of Liew and Hofmann (1988)

of granite crystallization. Two analyses of the core yield a concordia age of $1511 \pm 10 \mathrm{Ma}(\mathrm{MSWD}=1.5)$ and a mean ${ }^{207} \mathrm{~Pb} / 206 \mathrm{~Pb}$ age of $1508 \pm 10 \mathrm{Ma}$. The core therefore probably represents Mesoproterozoic inheritance from the granite protolith.

Only monazite was recovered from sample H1072. Grains are clear to slightly cloudy, yellowish, usually idiomorphic, equant to prismatic, and 60 to $200 \mu \mathrm{m}$ in diameter. The U contents vary from 560 to $2100 \mathrm{ppm}$ with $\mathrm{Th} / \mathrm{U}$ ratios of 8.6 to 127 (Tab. 6). Thirteen spots on 13 grains yield a concordia age of $506 \pm 6 \mathrm{Ma}$, which is within error of the mean $\mathrm{Th}-\mathrm{Pb}$ age of $513 \pm 5 \mathrm{Ma}$ (Fig. 6). These are interpreted as reflecting the crystallization of the granite and indicating that the granites H1072 and H1073 were formed during the same magmatic event.

The ${ }^{40} \mathrm{Ar} * /{ }^{39} \mathrm{Ar}$ age obtained from muscovite of the pegmatite dyke cutting the granite of the Burd Gol Granite Massif (sample H0161) corresponds to $485.1 \pm 3.2$ $\mathrm{Ma}$ (Fig. 7). Considering the low closure temperatures $\left(\sim 300-400{ }^{\circ} \mathrm{C}\right.$, Hames and Bowring 1994$)$ for Ar-Ar system in muscovite compared to the closure temperatures for $\mathrm{U}-\mathrm{Pb}$ system in zircon and the likely time span of the massif evolution, in which the pegmatite dyke reflects the final magmatic stages, all the geochronological results are in accord.

\section{Characteristics of the Boomyn Khudag Formation}

The Boomyn Khudag Formation defined by Hanžl and Aichler eds (2007) corresponds to a part of sedimentary rock sequence described by Rauzer et al. (1987) as an undifferentiated Lower-Middle Devonian formation. It is exposed in a narrow NW-SE oriented belt between Boomyn Khudag and Khooroiin Khudag (Fig. 2) at western tips of the Zamtyn Nuruu and Unegt Uul mountain ranges. These sediments do not contain any palaeontological record that would enable to determine their age. They unconformably overlie the Neoproterozoic metamorphic rocks of the Zamtyn Nuruu and form the footwall of the Permian volcanics. These sediments were intruded by Burd Gol Massif, which encloses thermally metamorphosed septa of sandstones in its northern part. The lithologic character of these metasediments corresponds to the Boomyn Khudag Formation.
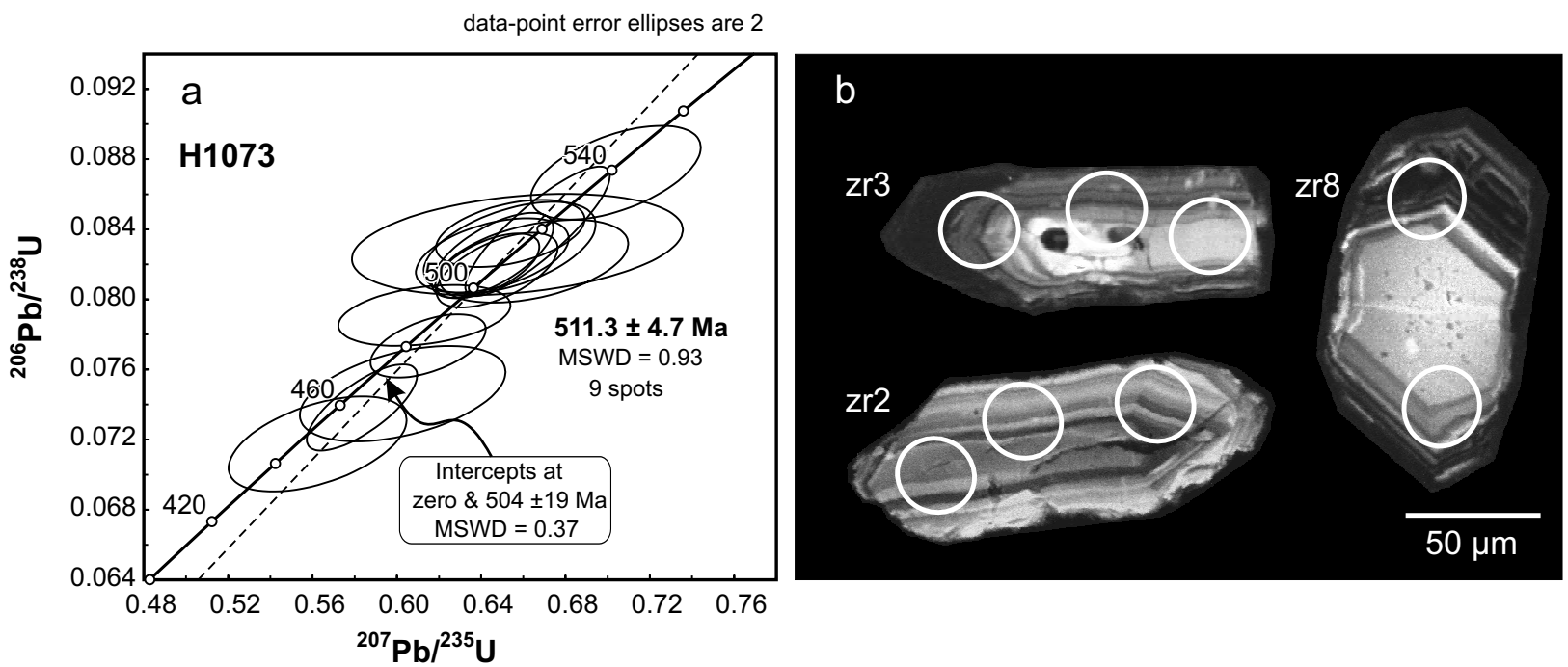

Fig. 5 Concordia diagram showing the ICP-MS analyses of zircon grains (a) and CL images of zircon (b) from the sample H1073. 


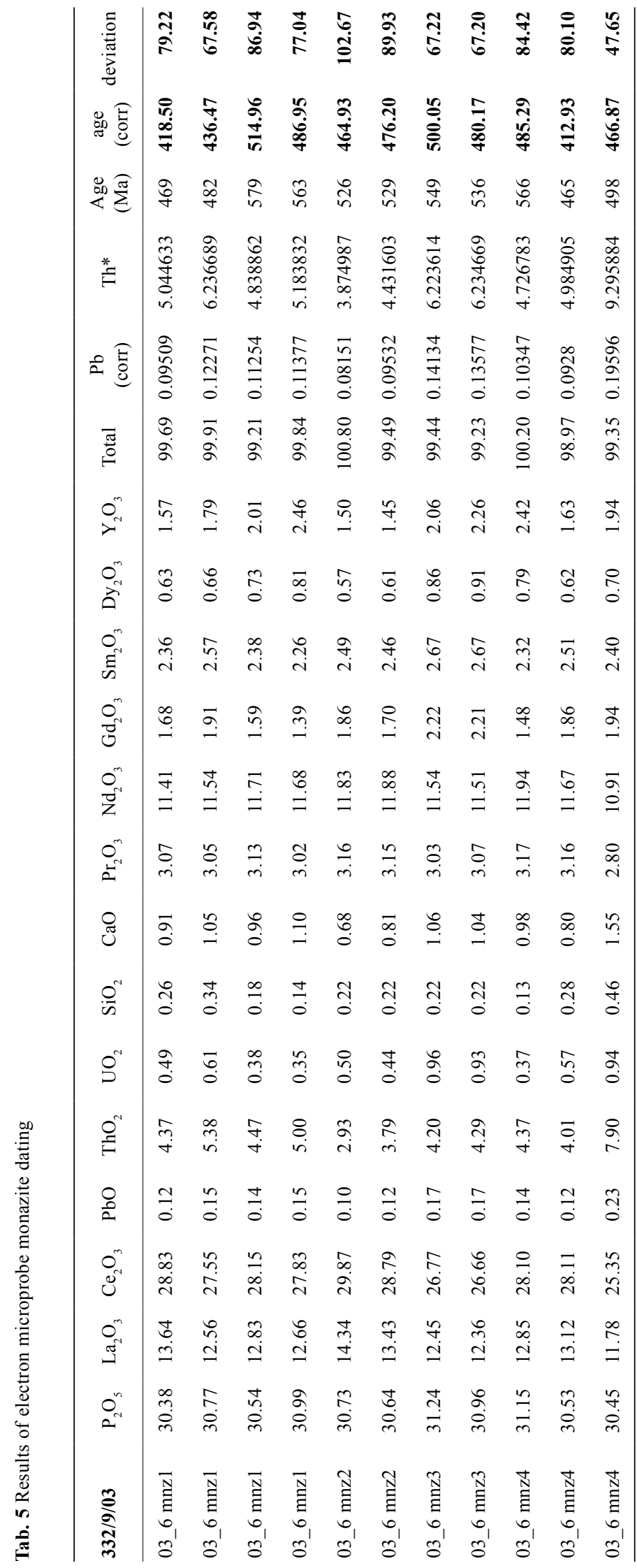

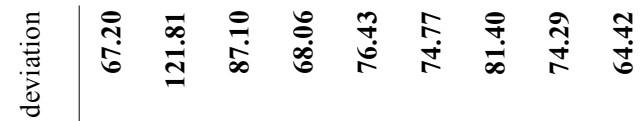

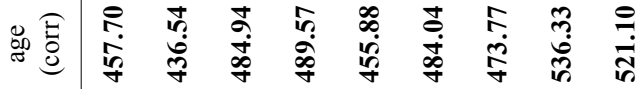

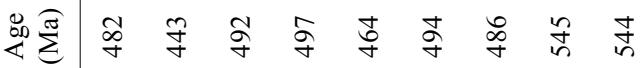

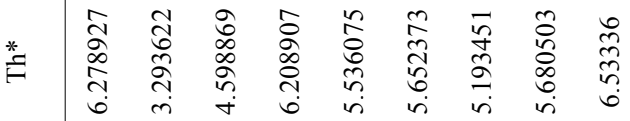

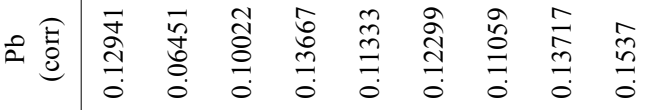
ส 。

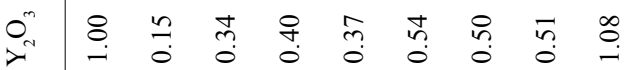
مे 0

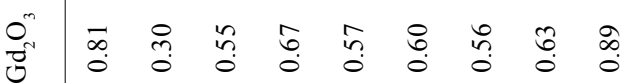
ठํㅁ

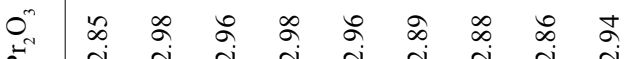

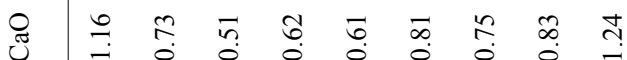

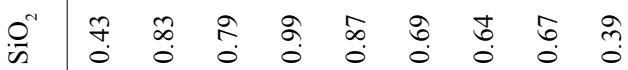

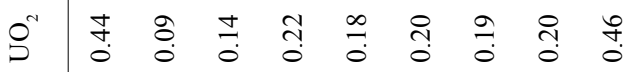

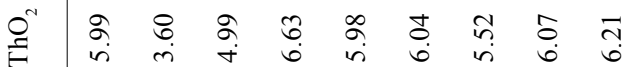

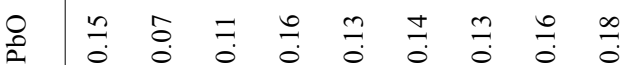

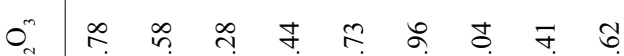
ن

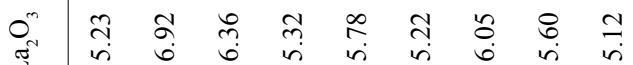

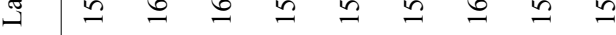

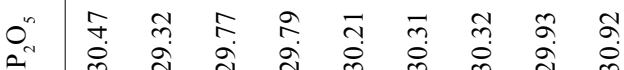

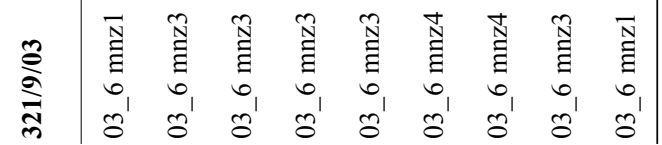


Tab. 6 LA-ICP-MS U, Pb and Th isotope data of dated monazite grains from granite $\mathrm{H} 1072$

\begin{tabular}{|c|c|c|c|c|c|c|c|c|c|c|c|c|c|c|c|c|}
\hline \multirow[b]{2}{*}{ No. } & \multirow{2}{*}{\multicolumn{2}{|c|}{$\begin{array}{l}{ }^{207} \mathrm{~Pb}^{\mathrm{a}} \quad \mathrm{U}^{\mathrm{b}} \quad \mathrm{Pb}^{\mathrm{b}} \\
(\mathrm{cps})(\mathrm{ppm})(\mathrm{ppm})\end{array}$}} & \multirow[b]{2}{*}{$\frac{\mathrm{Th}^{\mathrm{b}}}{\mathrm{U}}$} & \multicolumn{9}{|c|}{ Isotope ratios ${ }^{\mathrm{c}}$} & \multicolumn{4}{|c|}{ Ages (Ma) } \\
\hline & & & & $\frac{{ }^{206} \mathrm{~Pb}}{{ }^{204} \mathrm{~Pb}}$ & $\frac{{ }^{206} \mathrm{~Pb}}{{ }^{238} \mathrm{U}}$ & $\begin{array}{l} \pm 2 \sigma \\
(\%)\end{array}$ & $\frac{{ }^{207} \mathrm{~Pb}}{{ }^{235} \mathrm{U}}$ & $\begin{array}{l} \pm 2 \sigma \\
(\%)\end{array}$ & rho $^{d}$ & ${ }^{{ }^{207} \mathrm{~Pb}}$ & $\begin{array}{l} \pm 2 \sigma \\
(\%)\end{array}$ & $\begin{array}{ll}{ }^{208} \mathrm{~Pb} & \pm 2 \sigma \\
\frac{232}{23 h} & (\%)\end{array}$ & $\frac{{ }^{206} \mathrm{~Pb}}{{ }^{238} \mathrm{U}} \pm 2 \sigma \frac{2}{2}$ & $\frac{{ }^{207} \mathrm{~Pb}}{{ }^{235} \mathrm{U}} \pm 2 \sigma$ & $\frac{{ }^{207} \mathrm{~Pb}}{{ }^{206} \mathrm{~Pb}} \pm 2 \sigma$ & 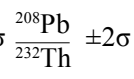 \\
\hline $\mathrm{z} 1$ & $15757 \quad 883$ & 1715 & 76 & 1147 & 08340 & 30 & 0.6575 & 4.3 & 0.69 & 0572 & 3.1 & $\begin{array}{lll}0.02608 & 1.7\end{array}$ & $516 \pm 15$ & $5513 \pm 44$ & $498 \pm 68$ & $520 \pm 9$ \\
\hline Mz2 & 1108942015 & 1225 & 22 & 724 & 0.07980 & 3.2 & 0.6381 & 3.6 & 0.89 & 580 & 1.6 & 0.025531 .8 & $495 \pm 16$ & $6501 \pm 36$ & $529 \pm 35$ & $509 \pm 9$ \\
\hline Mz3 & 536211724 & 473 & 8.6 & 25002 & 0.07958 & 2.9 & 0.6318 & 3.2 & 0.90 & 0.0576 & 1.4 & $\begin{array}{lll}0.02536 & 1.7\end{array}$ & $494 \pm 14$ & $4 \quad 497 \pm 31$ & $514 \pm 30$ & $506 \pm 9$ \\
\hline $\mathrm{Mz} 4$ & 804582099 & 1129 & 19 & 1044 & 0.08110 & 3.2 & 0.6479 & 3.5 & 0.90 & 0.0579 & 1.5 & $\begin{array}{lll}0.02530 & 1.7\end{array}$ & $503 \pm 16$ & $6507 \pm 36$ & $528 \pm 34$ & $505 \pm 9$ \\
\hline 20 & 435121229 & 506 & 13 & 690 & 224 & 2.8 & 6509 & 3.3 & 0.87 & 574 & 1.6 & $0.02574 \quad 1.9$ & $509 \pm 15$ & $5509 \pm 33$ & 507 & 314 \\
\hline Mz6 & $27371 \quad 561$ & 1919 & 127 & 306 & 0.08099 & 3.4 & 0.6420 & 3.8 & 0.89 & 0.0575 & 1.7 & $0.02522 \quad 1.9$ & $502 \pm 17$ & $7504 \pm 38$ & $510 \pm 38$ & $504 \pm 10$ \\
\hline IVIZI & 69281430 & 1386 & 36 & 8770 & 0.08367 & 3.0 & 0.6620 & 3.3 & 0.92 & 0.0574 & 1.3 & $0.02611 \quad 1.8$ & $518 \pm 16$ & $6516 \pm 34$ & $506 \pm 29$ & $521 \pm 9$ \\
\hline Mz8 & 172621160 & 1024 & 32 & 9037 & 0.07956 & 3.0 & 0.6266 & 4.0 & 0.75 & 0.0571 & 2.7 & $0.02593 \quad 1.8$ & $494 \pm 15$ & $5494 \pm 40$ & $496 \pm 59$ & $517 \pm 9$ \\
\hline Mz9 & 394951214 & 1151 & 36 & 10275 & 0.08100 & 2.9 & 0.6420 & 3.3 & 0.89 & 0.0575 & 1.5 & $\begin{array}{lll}0.02614 & 1.7\end{array}$ & $502 \pm 15$ & $5504 \pm 33$ & $510 \pm 34$ & $521 \pm 9$ \\
\hline Mz10 & 535081300 & 456 & 11 & 06 & 0.08310 & 3.3 & 0.6636 & 3.7 & 0.90 & 0.0579 & 1.6 & $\begin{array}{lll}0.02585 & 1.7\end{array}$ & $515 \pm 17$ & $7517 \pm 38$ & $526 \pm 35$ & $516 \pm 9$ \\
\hline Mz11 & 14183978 & 1981 & 79 & 6151 & 0.08207 & 2.8 & 0.6496 & 3.6 & 0.78 & 0.0574 & 2.3 & $\begin{array}{lll}0.02603 & 1.7\end{array}$ & $508 \pm 14$ & $4508 \pm 37$ & $507 \pm 50$ & $519 \pm 9$ \\
\hline Mz1 & 2257761723 & 835 & 15 & 494 & 0.08086 & 3.4 & 0.6394 & 4.1 & 0.83 & 0.0573 & 2.3 & $0.02542 \quad 1.9$ & $501 \pm 17$ & $7502 \pm 41$ & $505 \pm 51$ & $507 \pm 10$ \\
\hline Mz13 & 1827021567 & 1055 & 23 & 355 & 0.08268 & 3.0 & 0.6566 & 3.7 & 0.82 & 0.0576 & 2.1 & 0.025701 .8 & $512 \pm 16$ & $6513 \pm 38$ & $514 \pm 46$ & $513 \pm 9$ \\
\hline
\end{tabular}

a within-run background-corrected mean ${ }^{207} \mathrm{~Pb}$ signal in counts per seconds. ${ }^{\mathrm{b}} \mathrm{U}$ and $\mathrm{Pb}$ content and $\mathrm{Th} / \mathrm{U}$ ratio were calculated relative to monazite reference and are accurate to approximately $20 \%$ due to heterogeneity of the reference monazite. ${ }^{\mathbf{c}}$ corrected for background, mass bias, laser induced U-Pb fractionation and common $\mathrm{Pb}$ using Stacey and Kramers $(1975)$ model $\mathrm{Pb}$ composition. ${ }^{207} \mathrm{~Pb} /{ }^{235} \mathrm{U}$ calculated using ${ }^{207} \mathrm{~Pb} /{ }^{206} \mathrm{~Pb} /\left({ }^{238} \mathrm{U} / 206 \mathrm{~Pb}\right.$ $\times 1 / 137.88)$. Uncertainties are propagated by quadratic addition of within-run precision (2SE) and the reproducibility of standard (2SD). ${ }^{\mathbf{d}} \mathrm{Rho}$ is the error correlation defined as $\operatorname{err}^{206} \mathrm{~Pb} /{ }^{238} \mathrm{U} / \mathrm{err}^{207} \mathrm{~Pb} / 235 \mathrm{U}$.

Tab. 7 LA-ICP-MS U, Pb and Th isotope data of dated zircon grains from granite H1073

\begin{tabular}{|c|c|c|c|c|c|c|c|c|c|c|c|c|c|c|c|c|c|c|}
\hline \multirow[b]{2}{*}{ No. } & \multirow[b]{2}{*}{$\begin{array}{r}{ }^{207} \mathrm{~Pb}^{\mathrm{a}} \\
(\mathrm{cps})\end{array}$} & \multirow[b]{2}{*}{$\begin{array}{c}\mathrm{U}^{\mathrm{b}} \\
(\mathrm{ppm})\end{array}$} & \multirow[b]{2}{*}{$\begin{array}{c}\mathrm{Pb}^{\mathrm{b}} \\
(\mathrm{ppm})\end{array}$} & \multirow[b]{2}{*}{$\frac{\mathrm{Th}^{\mathrm{b}}}{\mathrm{U}}$} & \multicolumn{8}{|c|}{ Isotope ratios ${ }^{\mathrm{c}}$} & \multicolumn{6}{|c|}{ Ages (Ma) } \\
\hline & & & & & $\frac{{ }^{206} \mathrm{~Pb}}{{ }^{204} \mathrm{~Pb}}$ & $\frac{{ }^{206} \mathrm{~Pb}^{*}}{{ }^{238} \mathrm{U}}$ & $\begin{array}{l} \pm 2 \sigma \\
(\%)\end{array}$ & $\frac{{ }^{207} \mathrm{~Pb}^{*}}{{ }^{235} \mathrm{U}}$ & $\begin{array}{l} \pm 2 \sigma \\
(\%)\end{array}$ & $\frac{{ }^{207} \mathrm{~Pb}^{*}}{{ }^{206} \mathrm{~Pb}^{*}}$ & $\begin{array}{l} \pm 2 \sigma \\
(\%) \\
\end{array}$ & $h^{d}$ & $\frac{{ }^{207} \mathrm{~Pb}}{{ }^{235} \mathrm{U}}$ & $\pm 2 \sigma$ & $\frac{{ }^{206} \mathrm{~Pb}}{{ }^{238} \mathrm{U}}$ & $\pm 2 \sigma$ & ${ }^{207} \mathrm{~Pb}$ & $\pm 2 \sigma$ \\
\hline & 5231 & 362 & 105 & 0.47 & 23668 & 0.2671 & 1.8 & 3.4790 & 2.0 & .09448 & 0.9 & & 1522 & 30 & 1526 & 27 & 1518 & 16 \\
\hline & 102753 & & 165 & 043 & 6540 & 2618 & 2.4 & & 2.5 & 0.09366 & 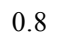 & 0.95 & 1500 & 37 & 499 & 36 & 501 & 15 \\
\hline 7 & & 1 & 1 & 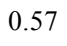 & 1111 & & 1 & & 5.4 & & .1 & & 486 & 26 & 491 & & 461 & 114 \\
\hline 0 & 5055 & 158 & 14 & 047 & 500 & 00810 & 1 & 9 & 3.1 & 3 & 2.5 & ה. & 504 & 10 & 508 & & 489 & 56 \\
\hline e & 05 & 227 & 2 & 0.47 & 502 & 838 & 1.9 & & 4.4 & 1 & 0 & 0.42 & 511 & 23 & 519 & 10 & 476 & 38 \\
\hline 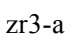 & (1) & 202 & 52 & 1.10 & 1509 & 1022 & 2.3 & 0.6650 & $3 . J$ & 0.05869 & 5.0 & 0.10 & 518 & 20 & 509 & 12 & 556 & 108 \\
\hline $7 r^{3}-h$ & 16848 & 216 & 28 & 1.17 & 2164 & 821 & 2.8 & 0.6572 & 9.8 & 0.05734 & 9.3 & 020 & 513 & 50 & 515 & 15 & 504 & 206 \\
\hline 政 & & 695 & 262 & 1.09 & 1305 & & 1.9 & & 3.6 & & 3.1 & & 487 & 10 & 4 & 3 & 517 & 68 \\
\hline 4 & 409 & 572 & 287 & 1.57 & 1679 & 738 & 2.7 & 35 & 3.7 & 731 & 2.4 & 078 & 467 & 17 & 459 & 13 & 504 & 54 \\
\hline r6-a & $-200-$ & 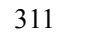 & 6 & & & & 3. & & 6.6 & & 5.9 & & 479 & 20 & 464 & & 2 & 129 \\
\hline $6-b$ & 5358 & 261 & 54 & 0.4 & 1018 & 0830 & 3.6 & 0.6668 & 4.2 & 0.05765 & 2.2 & 08 & 519 & 22 & 519 & 10 & 517 & 48 \\
\hline $\mathrm{zr} 2-\mathrm{a}$ & 4778 & 257 & 22 & 0.5 & 247 & & 2.1 & & 4.6 & & 4.1 & & 506 & 23 & 511 & 11 & 481 & (200 \\
\hline$z r 2-b$ & 4978 & 265 & 22 & 0.38 & 5676 & 817 & 2.1 & 0.6475 & 3.6 & 0.05750 & 2.9 & 050 & 507 & 18 & 506 & 11 & 511 & . \\
\hline r2- & 4619 & 252 & 22 & 0 & 4119 & 0.0020 & 2. & t & 3. & -0. & 2. & 0.6 & 506 & 18 & 3 & 12 & 481 & 01 \\
\hline 5 & & 40 & 3.7 & 0 & 1409 & & 2 & & 5.1 & & 4.4 & & 511 & 20 & 514 & 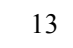 & 497 & 97 \\
\hline$\angle I J-0$ & 1981 & 91 & 9.1 & 0.5 & 225 & 012 & 2.3 & 39 & 4.1 & 852 & 3.9 & 0.54 & 541 & 25 & 539 & 14 & 549 & 00 \\
\hline 4-b & 424 & 323 & 6 & 0.6 & 2022 & 718 & 3.1 & 5624 & 6.1 & 0 . & 5.3 & 0.50 & 453 & 28 & 447 & 14 & 486 & 117 \\
\hline
\end{tabular}

a within-run background-corrected mean ${ }^{207} \mathrm{~Pb}$ signal in counts per seconds. ${ }^{\mathbf{b}} \mathrm{U}$ and $\mathrm{Pb}$ content and $\mathrm{Th} / \mathrm{U}$ ratio were calculated relative to GJ-1 reference and are accurate to approximately $10 \%$ due to heterogeneity of the GJ-1 zircon. ${ }^{\mathbf{c}}$ corrected for background, mass bias, laser induced $\mathrm{U}-\mathrm{Pb}$ fractionation and common $\mathrm{Pb}$ using Stacey and Kramers (1975) model $\mathrm{Pb}$ composition. ${ }^{207} \mathrm{~Pb} /{ }^{235} \mathrm{U}$ calculated using ${ }^{207} \mathrm{~Pb} /{ }^{206} \mathrm{~Pb} /\left({ }^{238} \mathrm{U} /{ }^{206} \mathrm{~Pb} \times\right.$ $1 / 137.88)$. Uncertainties are propagated by quadratic addition of within-run precision (2SE) and the reproducibility of GJ-1 (2SD). ${ }^{d}$ Rho is the error correlation defined as $\mathrm{err}^{206} \mathrm{~Pb} / 238 \mathrm{U} / \mathrm{err}^{207} \mathrm{~Pb} / 235 \mathrm{U}$. 
data-point error ellipses are $2 \sigma$
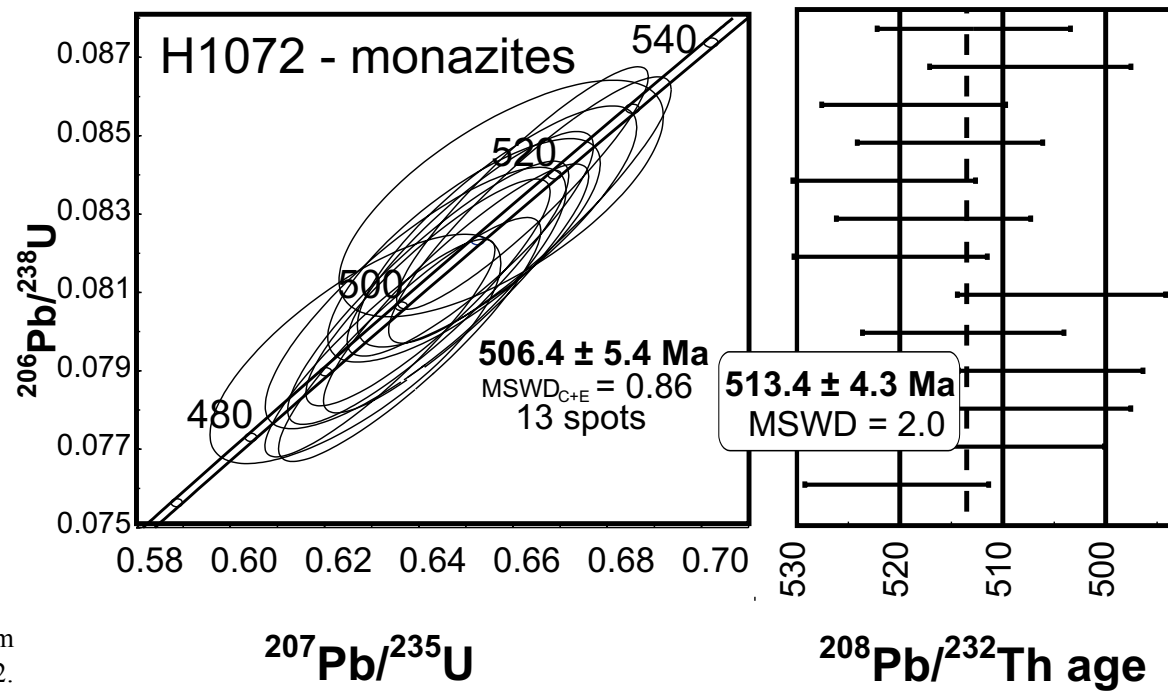

Fig. 6 ICP-MS monazite age of granites from the Burd Gol Granite Massif, sample H1072.

\subsection{Sedimentology}

The Boomyn Khudag Formation is formed mainly by conglomerates. They are characterized as red to light brown, massive, matrix-supported, poorly sorted, ungraded cobble conglomerates. The conglomerates locally alternate with small lenses and layers of medium-grained, massive sandstones. The cobbles of average diameter of c. $8 \mathrm{~cm}$ (A-axis) and maximum size of $c .1 \mathrm{~m}$ are wellrounded, consisting of gneisses, basalts, undifferentiated volcanic rocks, cherts and quartz in particular. Matrix is composed of grains of quartz, K-feldspars, plagioclases and rock fragments. Biotite and carbonates are also present. The massive cobble conglomerates correspond to lithofacies $\mathrm{Gm}$ and massive sandstones to lithofacies $\mathrm{Sh}$ (according to Miall 1978 and Bridge 1993).

Red to purple-red, very coarse- to fine-grained arkosic sandstones and arkoses with layers of mudstones and siltstones occur in the hanging wall of the conglomerates. They are poorly sorted, being composed mainly of subrounded to subangular grains of quartz, K-feldspar and plagioclase. Quartz grains predominate; K-feldspars and plagioclases are present in variable amounts. Micas and ultra-stable minerals (zircon, tourmaline, rutile), ore minerals, zoisite, epidote and monazite are the common accessories. Sharp fragments of vitrite and volcanic rocks are rarely present. Basal matrix is composed of clay minerals (locally sericitized), chlorite and carbonate.

A section, $43 \mathrm{~m}$ long, of arkosic sandstones and arkoses with layers of mudstones and siltstones has been studied in detail (Fig. 8). The sedimentary profile is situated near Ondor Ovoot Uul (see the asterisk in Fig. 2). Four lithofacies ( $F m, S h, S t$ and $S m$ according to Miall 1978 and Bridge 1993) have been recognized within the logged profile on the basis of sedimentary textures and structures.

Lithofacies $S m$ consists of massive very coarse- to fine-grained arkosic sandstone and arkose. These are poorly sorted and contain clasts of red-brown mudstones, which are concentrated near the base of the beds. Semiangular quartz and feldspar grains occur as the commonly recognizable clasts. Normal grading can be observed to

Fig. $7^{40} \mathrm{Ar} /{ }^{39} \mathrm{Ar}$ release spectrum from muscovites in the pegmatite dyke, sample H0161, Burd Gol Granite Massif.

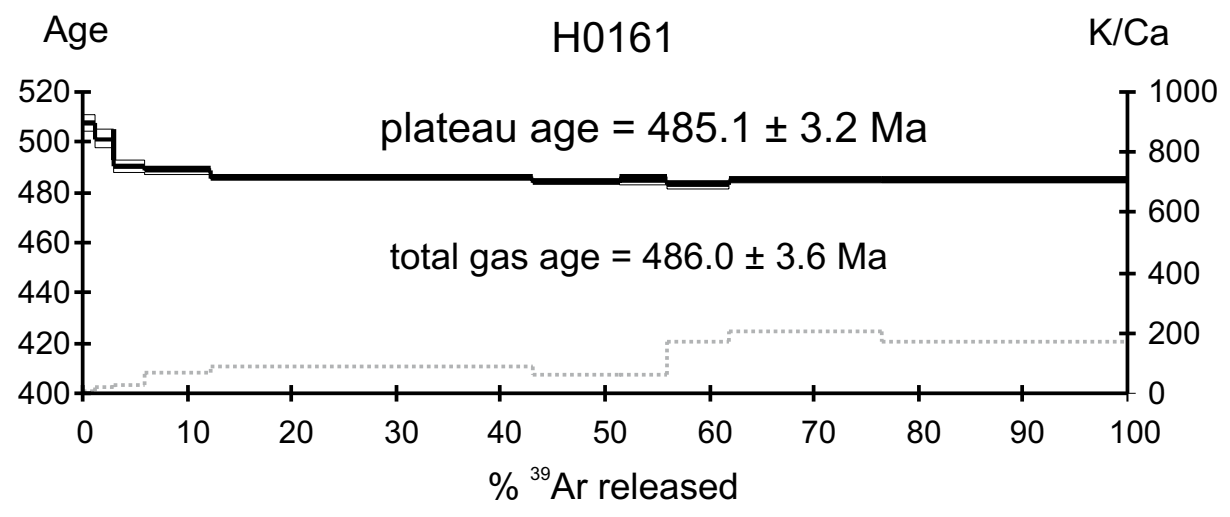




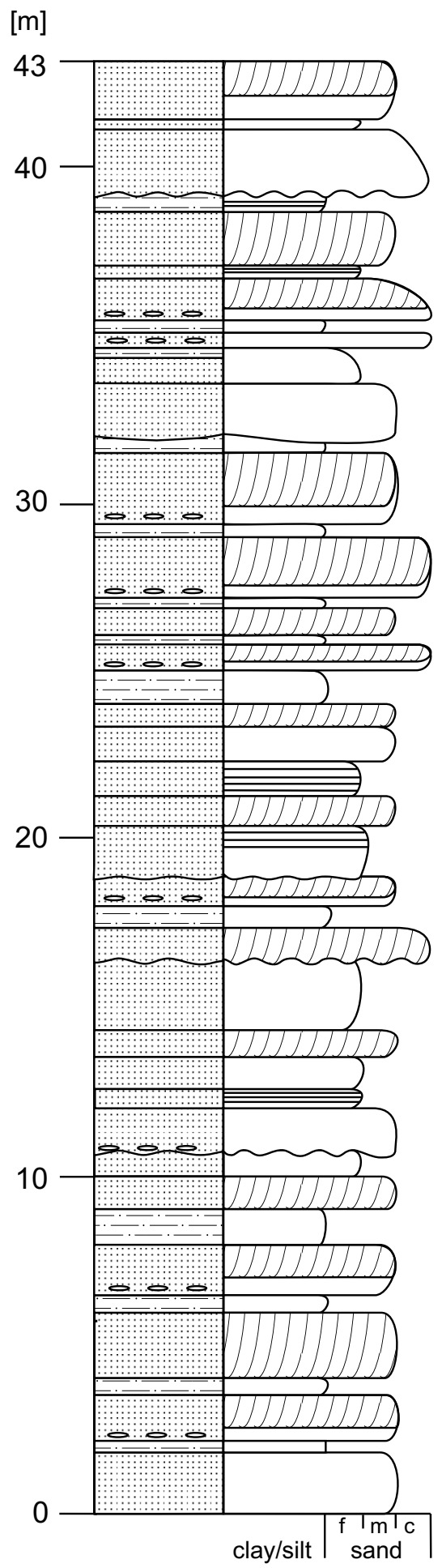

LEGEND

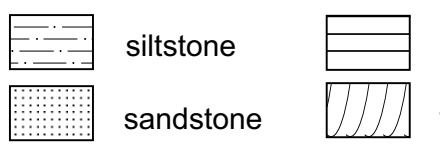

horizontal lamination

trough cross bedding

$\propto$ intraclasts of mudstone

Fig. 8 The log of the sedimentary profile of the Boomyn Khudag Formation studied in the vicinity of the homonymic well. fining upwards of sandstone grains. The bases of the beds are mainly sharp or erosive. Bed thickness ranges from 0.4 to $2.0 \mathrm{~m}$. The $S m$ lithofacies commonly passes to lithofacies $S t$. Lithofacies $S m$ represents $45 \%$ of the studied profile.

Lithofacies $S t$ is characterized by medium- to coarsegrained trough-cross-bedded arkosic sandstones to arkoses. Darker small layers of fine-grained sandstones emphasise cross-bedding. Bed thickness ranges from 0.3 to $1.5 \mathrm{~m}$. Lithofacies $S t$ represents about $34 \%$ of the logged profile and mainly passes gradually from sandstones of the lithofacies Sm.

Lithofacies $S h$ consists of fine to medium-grained, horizontally laminated arkosic sandstones. Sandstones of lithofacies $S t$ often pass to sandstones of lithofacies $S h$. The thickness ranges between 0.2 to $0.5 \mathrm{~m}$. Lithofacies $S h$ represents only $6 \%$ of the studied profile.

Lithofacies $F m$ is formed by red mudstones, siltstones and very fine sandstones, massive or parallel laminated. Rocks alternate in layers from first millimetres to first centimetres thick. Lithofacies $F m$ occurs as interbeds within lithofacies $S t$ or $S m$. Lithofacies $F m$ represents $15 \%$ of the studied profile.

\subsection{The thermally-metamorphosed arkose septa within the Burd Gol Massif}

The rocks are represented by medium-grained red arkoses to arkosic sandstones with intercalations and layers of siltstones and mudstones. Sedimentary bedding is preserved; locally, small-scale structures such as cross bedding can be observable. The mineral composition corresponds to original quartzo-feldspathic arkoses with no preserved matrix and with the relics of the rock fragments, stable minerals as zircon and rutile are relatively common accessories. The newly formed muscovite porphyroblasts, quartz recrystallization and extensive silicification bear evidence of thermal and fluid affection during the granite emplacement.

\section{Discussion}

The Lake Zone forms a belt of various rocks of Neoproterozoic to Lower Palaeozoic ages rimming the Main Mongolian Lineament from the north. It is a part of the eastern segment of CAOB which is considered to be associated with the Early Caledonian tectogenesis (570-510 Ma) (e. g. Kröner et al. 2007).

The southeastern-most part of the Lake Zone is formed by an accretionary wedge developed south of the Baydrag basement Block (Bibikova et al. 1990; Kotov et al. 1995; Dergunov 2001; Kozakov et al. 2007; Windley et al. 2007; Demoux et al. 2009). The metamorphosed 
rocks and terrestrial sediments of the Lake Zone were intruded here by the small Burd Gol Granite Massif, emplacement of which corresponds with a period of thermal reworking of the Lake Zone at $\sim 500 \mathrm{Ma}$ (Kröner et al. 2010).

\subsection{Depositional character of sediments in the roof of the Burd Gol Massif}

Conglomerates, sandstones, mudstones and siltstones of the Boomyn Khudag Formation are terrestrial sediments deposited in arid and semiarid conditions. The lithofacial transitions $\mathrm{Gm}-\mathrm{Sm}$ were mostly caused by catastrophic sheetfloods. The facial association could be the most likely interpreted as sediments of debris-flows deposited in alluvial fans eventually or as cores of levees of a braided river (Ramos and Sopeña 1983; Miall 1996; Bridge 2003).

The Sm-St-(Sh)-Fm facial association corresponds to products of coarse-grained water flow sediments (most probably a braided river), deposited in intermediate to distal part of an alluvial fan. The facial association may be interpreted as sediments of levees and transverse bars (Ramos and Sopeña 1983; Miall 1996; Bridge 2003). Other possible interpretation can be a "channelling" typical of the distal parts of alluvial fans. The occurrences of $S h$ lithofacies in association with sediments of alluvial fans and coarse-grained water flow point to a periodic existence of sedimentation in a rapid flow regime and to a tendency to overflowing of the channels. The processes could have been seasonally and/or climatically controlled.

Within the northern part of the Burd Gol Granite Massif are preserved enclaves of amphibolites, gneisses, micaschists and septa of arkosic sandstones up to several tens of meters across. While metamorphic rocks are easily correlated with the Zamtyn Nuruu Metamorphic Complex, geological pertinence of sandstone xenoliths merits discussion. Volcanosedimentary complexes lying north of the Zamtyn Nuruu Complex (Khan Taishir and Naraan formations) are completely different in lithology and geological position. In addition, SHRIMP II ages from detrital zircons in sandstones corresponding with the Naraan Formation suggest a maximum Early Devonian depositional age of the unit (Kröner et al. 2010). Therefore, only sediments of the Boomyn Khudag Formation can be correlated with the arkose septa in the Burd Gol Granite Massif.

\subsection{The age and regional correlations}

The zircon and monazite ages of $\sim 510$ Ma reflect the crystallization of the pluton. Muscovite Ar-Ar dating on pegmatite dyke in this granite provided an age of 485.1 $\pm 3.2 \mathrm{Ma}$ which corresponds to final magmatic stages of the Burd Gol Granite Massif during the Late Cambrian to Early Ordovician. The magmatic age of the Burd Gol Granite Massif is well comparable with published geochronological data from the Lake Terrane (e. g. Hanžl and Aichler eds 2007; Kröner et al. 2010).

The plutonic rocks in Tuva region in Russia yielded ages of $512 \pm 4 \mathrm{Ma}$ (Pfänder et al. 2000). Jian et al. (2010) described the high-K calc-alkaline, peraluminous granites of Tsagaan Pluton situated $200 \mathrm{~km}$ NE from Burd Gol, emplacement ages of which were determined to 514 $\pm 10 \mathrm{Ma}$, with an 558-646 Ma inheritance. Demoux et al. (2009), who collected a series of geochronological data from Baydrag Block, described syntectonic granitic rocks $519 \pm 9 \mathrm{Ma}$ old from the Taats river area. The garnet granite from southern domain of Tatsain Metamorphic Complex (Kozakov et al. 2008) yielded slightly older zircon ages $(532 \pm 9 \mathrm{Ma})$

Mesoproterozoic inheritance of zircon grains from Burd Gol granite ranging between 1.508 and $1.511 \mathrm{Ga}$ corresponds to the concept of the Lake Island Arc formed on Late Neoproterozoic oceanic crust and developed during Cambrian to Early Ordovician presented by Badarch et al. (2002) based on data of Kröner et al. (2001). Demoux et al. (2009) determined the inherited zircon ages 3.12 and $1.99 \mathrm{Ga}$ of rocks of Baydrag Block and 1.84-1.83 Ga for the rocks of Bumbuger Complex north of the Lake Zone.

\subsection{The geotectonic position of the Burd Gol Granite Massif}

Major element geochemistry of the Burd Gol granites points to evolved rocks with subaluminous to slightly peraluminous affinity; the low $\mathrm{Rb} / \mathrm{Sr}$ ratios indicate relatively primitive source of magma. The REE patterns are well fractionated but mostly lacking sizeable Eu anomalies.

Isotopic composition shows rather unradiogenic $\mathrm{Nd}$ $\left(\varepsilon_{N d}^{510}=-1.5\right.$ and -0.2$)$ with correspondingly high twostage $\mathrm{Nd}$ crustal residence ages $\left(\mathrm{T}_{N d}^{D M}=1.3\right.$ and $\left.1.2 \mathrm{Ga}\right)$, corresponding to the Precambrian isotope province of Central Asian Mobile Belt according Kovalenko et al. (2004). Significantly less evolved strontium $\left({ }^{87} \mathrm{Sr} /{ }^{86} \mathrm{Sr}_{510}=\right.$ 0.7064 ) shows a little fractionated crustal source with low time-integrated $\mathrm{Rb} / \mathrm{Sr}$ ratio.Trace-element signature is marked by the depletion in $\mathrm{Nb}$ and $\mathrm{Ti}$ which is indicative of arc magmatism (Wilson 1989; Draut and Clift 2002). A magmatic-arc setting is also indicated by the geotectonic discrimination diagrams of Pearce et al. (1984) and Schandl and Gorton (2002) (Fig. 9a-b).

Following the geological relationships, the Burd Gol Granite Massif intruded at an active continental margin geotectonic setting. The possible role for assimilation of the roof represented by gneisses, amphibolites and clastic sediments may be indicated also by higher $\mathrm{K}_{2} \mathrm{O}$ 

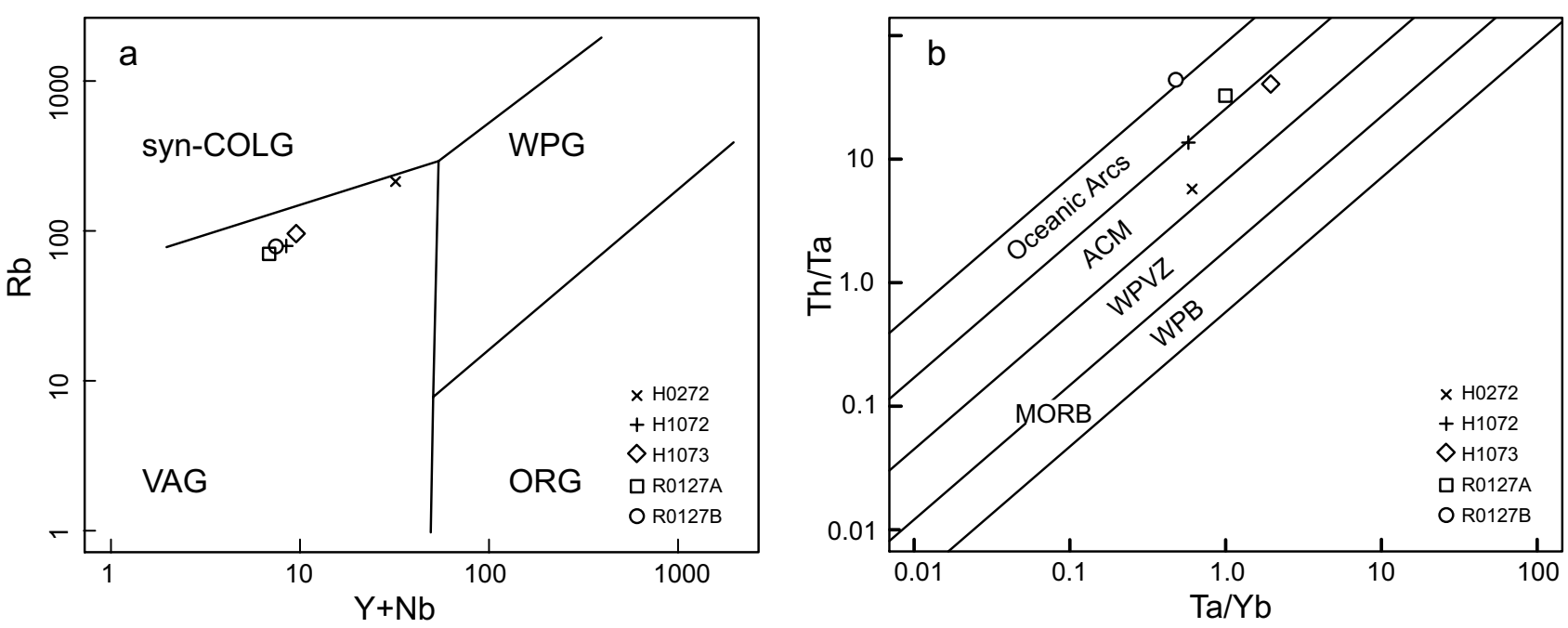

Fig. 9 Geotectonic discrimination diagrams for granites of the Burd Gol Massif. a - Geotectonic discrimination diagram Rb vs. $\mathrm{Y}+\mathrm{Nb}$ of Pearce et al. (1984). b - Geotectonic discrimination diagram Th/Ta vs. Ta/Yb according Schandl and Gorton (2002). Explanations: syn-COLG - synCollisional Granite; VAG - Volcanic Arc Granite; WPG - Within Plate Granite; ORG - Ocean Ridge Granite; ACM - Active Continental Margin; WPWZ - Within Plate Volcanic Zone; WPB - Within Plate Basalt; MORB - Mid-Ocean Ridge Basalt.

and $\mathrm{Pb}$ contents and slightly peraluminous character of the granites.

The granite sample H0272 from the southern part of the massif close to the fault boundary with the Gobi Altay Terrane differs in its $\mathrm{Rb} / \mathrm{Sr}$ ratio, trace-element signature and REE pattern from the rest of the dataset. It could be well correlated with leucogranites in tectonic mélange of the Unegt Uul Mt. (further east) which yielded zircons $518 \pm 5$ Ma old (Hrdličková et al. 2008).

The Burd Gol Granite Massif and Zamtyn Nuruu Complex represent the southern part (in the present coordinates) of the Cambrian collisional zone. Following the geological maps of the area (Buriánková and Hanžl eds 2007; Hanžl ed. 2007a) a hypothetic profile was drawn across the ancient subduction zone through the units in the SE tip of the Lake Zone (Fig. 10). From the North to South, it is oceanic crust preserved in the Khan Taishir ophiolite complex (Perfiliev and Kheraskov 1980), tectonic mélange of the high-pressure Alag Khadny Crystalline Complex (Hanžl ed. 2007a; Hanžl and Aichler eds 2007; Śtípská et al. 2010), slightly metamorphosed, relatively deep-water ramp sediments

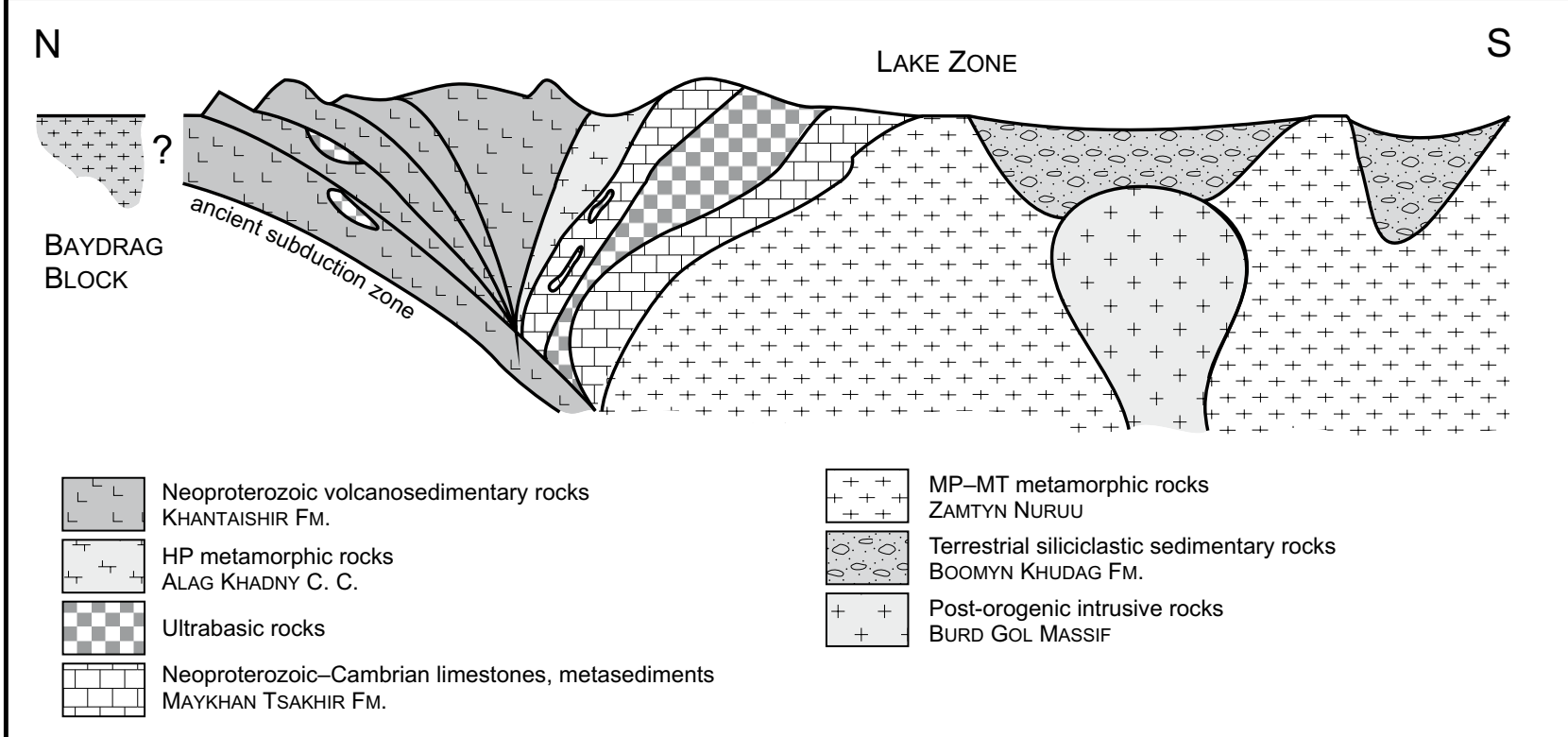

Fig 10 The hypothetic scheme of the post-collisional situation of the Lake Terrane during intrusion of the Burd Gol Granite Massif [in present day coordinates, according to Hanžl et al. (2007b)]. 
in a tectonic wedge and microcontinent represented by the Zamtyn Nuruu Complex with terrestrial molasselike sediments of the Boomyn Khudak Formation in the hanging wall (Fig. 10).

\section{Conclusions}

The Proterozoic high-grade metamorphic rocks and continental clastic sediments in their hanging wall (Zamtyn Nuruu range at the SE tip of the Lake Zone of the Central Asian Orogenic Belt) were intruded by the Burd Gol Granite Massif. The laser ablation ICP-MS U-Th-Pb zircon dating constrained its magmatic crystallization at $511 \pm 5 \mathrm{Ma}(2 \sigma)$, in agreement with the monazite age of $513 \pm 5 \mathrm{Ma}$. Muscovite ${ }^{40} \mathrm{Ar} /{ }^{39} \mathrm{Ar}$ dating of pegmatite dyke cutting this granite yielded an age of $485.1 \pm 3.2 \mathrm{Ma}$ timing the latest magmatic activity in the region.

Geochemical signature of granites indicates evolution in an active continental magmatic arc from the relatively mature crust $\left({ }^{87} \mathrm{Sr} /{ }^{86} \mathrm{Sr}_{510}=0.7064 ; \varepsilon_{N d}^{510}=-0.2\right.$ and -1.5$)$. Presence of ancient crust in the source of the Burd Gol Granite Massif is proven by the occurence of $\sim 1.5 \mathrm{Ga}$ old inherited zircon cores.

The sediments of the Boomyn Khudag Formation onlapping the metamorphic rocks of the Zamtyn Nuruu are indirectly dated as Cambrian, because they are affected by thermal metamorphism caused by the Burd Gol granite intrusion. Conglomerates, sandstones and siltstones of the Boomyn Khudag Formation are of terrestrial origin, deposited under arid or semiarid conditions in alluvial fans environment. Sedimentary character and transgressive position on the metamorphic rock of Zamtyn Nuruu indicate molasse-like character of the sediments.

The Burd Gol Granite Massif is a magmatic body cutting Proterozoic metamorphic rocks and Lower Palaeozoic terrestrial, molasse-like sediments in their hanging wall. Thus, the intrusion post-dated the Early Cambrian collision within the Lake Zone Terrane. As it lacks any effects of internal deformation, it can be designated as post-orogenic in relation to this event.

Acknowledgements. The presented data have been gathered within the framework of the project Zamtyn Nuruu-50 funded by the International Development Cooperation of the Czech Republic. It could not materialize without the logistic support by J. Holák and Z. Novotný and without the technical backing provided by Mongolian drivers and students, neither. We are indebted to V. Erban from the Radiogenic Isotopes Laboratory of the Czech Geological Survey, who made the $\mathrm{Sr}-\mathrm{Nd}$ isotopic data and to R. Čopjaková and R. Škoda from the Joint Electron Microanalysis Laboratory of the Masaryk University and the Czech Geological Survey in
Brno, who carried out microprobe analyses and CHIME monazite dating.

We are grateful to O. Gerel and J. Lehmann for helpful reviews. The careful editorial handling by M. Štemprok helped us to improve significantly the ideas expressed in this text. We owe also many thanks to editor in chief V. Janoušek for improvement of final version of the paper.

Electronic supplementary material. The GPS coordinates of the samples are available online at the Journal web site (http://dx.doi.org/10.3190/jgeosci.081).

\section{References}

Badarch G, Cunningham WD, Windley BF (2002) A new terrane subdivision for Mongolia: implications for the Phanerozoic crustal growth of central Asia. J Asian Earth Sci 21: 87-110

Balinnyam I, Bayasgalan A, Borisov BA, Cisternas A, Dem'yanovich MG, Ganbaatar L, Kochetkov VM, KuRushin RA, Molnar P, Philip H, Vashchilov YY (1993) Ruptures of Major Earthquakes and Active Deformation in Mongolia and Its Surroundings. Geological Society of America Memoirs 181: 1-62

Bibikova EV, Baikova VS, Gorohovskit BM, GracheVA TV, Kirnozova TI, Kozakov IK, Kotov AB, Neymark LA, Ovchinnikova GV, Sumin LV, Shuleshro IK (1990) Early Proterozoic boundary in the Baidrag Block in Central Mongolia. Proceedings of the Academy of Sciences of the USSR, Geology Series 7: 57-62 (in Russian)

Boynton WV (1984) Cosmochemistry of the rare earth elements: meteorite studies. In: HENDERSON P (ed) Rare Earth Element Geochemistry. Elsevier, Amsterdam, pp 63-114

BRIDGE J S (1993) Description and interpretation of fluvial deposits: a critical perspective. Sedimentology 40: $801-810$

BRIDGE JS (2003) Rivers and Floodplains. Blackwell Publishing, Oxford, pp 1-491

BuriánKovÁ K, HANŽL P (eds) (2007) Geological map of the Mongolian Altay on the scale of $1: 50,000$, map sheet L47-89G. Unpublished manuscript, Geological Information Centre, MRPAM, Ulaanbaatar

Cox KG, Bell JD, PANKhuRst RJ (1979) The Interpretation of Igneous Rocks. George Allen \& Unwin, London, pp 1-450

Demoux A, Kröner A, Badarch G, Jian P, Tomurhuu D, Wingate MTD (2009) Zircon ages from the Baydrag Block and the Bayankhongor Ophiolite Zone: time constraints on late Neoproterozoic to Cambrian subductionand accretion-related magmatism in Central Mongolia. J Geol 117: 377-397

Dergunov AB (2001) Tectonics, Magmatism, and Metallogeny of Mongolia. Routledge, London, pp 1-288 
DickIN AP (1997) Radiogenic Isotope Geology. Cambridge University Press, UK, pp 1-490

Draut AE, Clift PD (2002) The origin and significance of the Delaney Dome Formation, Connemara, Ireland. J Geol Soc, London 159: 95-103

Economos RC, Hanžl P, HrdličKová K, Buriánek D, Said L-O, Gerdes A, Paterson SR (2008) Geochemical and structural constraints on the magmatic history of the Chandman Massif of the eastern Mongolian Altay Range, SW Mongolia. J Geosci 53: 335-352

Gerdes A, Zeh A (2006) Combined U-Pb and Hf isotope LA-(MC-) ICP-MS analyses of detrital zircons: comparison with SHRIMP and new constraints for the provenance and age of an Armorican metasediments in Central Germany. Earth Planet Sci Lett 249: 47-61

Gerdes A, BuriánKová K (2007) Radiometric dating. In: HANŽL P, Aichler J (eds) Geological survey of the Mongolian Altay on the scale of 1: 50,000 (Zamtyn Nuruu - 50), Geological Information Centre, MRPAM, Ulaanbaatar, pp 205-217

Hames WE, Bowring SA (1994) An empirical evaluation of the argon diffusion geometry in muscovite. Earth Planet Sci Lett 124: 161-169

HANŽL P, AichleR J (eds) (2007) Geological survey of the Mongolian Altay on the scale of $1: 50,000$ (Zamtyn Nuruu - 50). Geological Information Centre, MRPAM, Ulaanbaatar, pp 1-376

HANŽL P (ed) (2007a) Geological map of the Mongolian Altay on the scale of $1: 50,000$, map sheet L47-89V. Unpublished manuscript, Geological Information Centre, MRPAM, Ulaanbaatar

HANŽL P (ed) (2007b) Geological map of the Mongolian Altay on the scale of $1: 50,000$, map sheet L47-101B. Unpublished manuscript, Geological Information Centre, MRPAM, Ulaanbaatar, pp 70-109

HANŽL P (ed) (2007c) Structural map of the Zamtyn Nuruu area; map sheet L47-89. Unpublished manuscript, Geological Information Centre, MRPAM, Ulaanbaatar

Hanžl P, Buriánek D, Rejchrt M, Buriánková K, Budil $P$ (2007a) Volcanosedimentary complexes of the Lake zone. In: HANŽL P, AICHLER J (eds) Geological survey of the Mongolian Altay on the scale of $1: 50,000$ (Zamtyn Nuruu - 50). Geological Information Centre, MRPAM, Ulaanbaatar, pp 1-376

HanžL P, Buriánek D, HrdičKová K, Aichler J, Gerdes A, ByAmbasuren D (2007b) Granitoid massifs of Zamtyn Nuruu Area, SW Mongolia. In: BreITER K (ed.) Abstracts of the $3^{\text {rd }}$ Meeting of Czech Geological Society, Volary, 19-22 September 2007. Czech Geological Society, Prague, pp 71 (in Czech)

HrdličKová K, Bolormaa K, Buriánek D, HanžL P, Gerdes A, JANOUŠEK V (2008) Petrology and age of metamorphosed rock in tectonic slices inside the Palaeozoic sediments of the eastern Mongolian Altay, SW Mongolia. J Geosci 53: 139-165

JaCOBSEN SB, WaSSERBURG GJ (1980) Sm-Nd evolution of chondrites. Earth Planet Sci Lett 50: 139-155

JAHN BM, Wu F, Chen B (2000) Massive granitoid generation in Central Asia: $\mathrm{Nd}$ isotope evidence and implication for continental growth in the Phanerozoic. Episodes 23: $82-92$

JAHN BM (2004) The Central Asian Orogenic Belt and growth of the continental crust in the Phanerozoic. In: Malpas J, Fletcher CJN, Ali JR, Aitchinson JC (eds) Aspects of the Tectonic Evolution of China. Geological Society of London Special Publications 226: pp 73-100

Jahn BM, Capdevila R, Liu D, Vernon A, Badarch G (2004) Sources of Phanerozoic granitoids in the transect Bayanhongor-Ulaan Baatar, Mongolia: geochemical and $\mathrm{Nd}$ isotopic evidence, and implications for Phanerozoic crustal growth. J Asian Earth Sci 23: 629-653

JANOUŠEK V, FARROW CM, ERBAN V (2006) Interpretation of whole-rock geochemical data in igneous geochemistry: introducing Geochemical Data Toolkit (GCDkit). J Petrol 47: 1255-1259

Jian P, Kröner A, Windley BF, Shi Y, Zhang F, Miao L, Tomurhuu D, Zhang W, Liu D (2010) Zircon ages of the Bayankhongor ophiolite mélange and associated rocks: time constraints on Neoproterozoic to Cambrian accretionary and collisional orogenesis in Central Mongolia. Precambr Res 177: 162-180

Kotov AB, Kozakov IK, Bibikova EV (1995) Duration of regional metamorphic episodes in area of polycyclic endogenic processes: a U-Pb geochronological study. Petrology 3: 567-575

Kovalenko VI, Yarmolyuk VV, Kovach VP, Kotov AB, Kozakov IK, Salnikova EB, Larin AM (2004) Isotope provinces, mechanisms of generation and sources of the continental crust in the Central Asian mobile belt: geological and isotopic evidence. J Asian Earth Sci 23: 605-627

Kozakov IK, Kotov AB, Salnikova EB, Bibikova EV, Kovach VP, Kirnozova TI, Berezhnaya NG, Lykhin DA (1999) Metamorphic age of crystalline complexes of the Tuva-Mongolia Massif: the U-Pb geochronology of granitoids. Petrology 7: 173-189

Kozakov IK, Kotov AB, Salnikova EB, Кovach, VP, Natman A, Bibikova EV, Kirnozova TI, Todt W, Kröner A, Yakovleva SZ, Lebedev VI, SugoraKOVA AM (2001) Timing of the structural evolution of metamorphic rocks in the Tuva-Mongolian Massif. Geotectonics 35: 22-43

Kozakov IK, Kovach VP, Bibikova EV, Kirnozova TI, Zagornaya NY, Plotkina YV, Podkovyrov VN (2007) Age and sources of granitoids in the junction zone of the Caledonides and Hercynides in southwestern Mongolia: geodynamic implications. Petrology 15: 126-150 
Kozakov IK, Salnikova EB, Kovach VP, Yarmolyuk VV, Anisimova IV, Kozlovskil AM, Plotkina YV, Myskova TA, Fedoseenko AM, Yakovleva SZ, Sugorakova AM (2008) Vendian stage in formation of the Early Caledonian Superterrane in Central Asia. Strat Geol Correlation 16: 360-382

Kröner A, Tomurtogoo O, Badarch G, Windley BF, KozAKov IK (2001) New zircon ages and significance for crustal evolution in Mongolia. In: SKLyAROV EV (ed) Assembly and Breakup of Rodinia Supercontinent: Evidence from South Siberia. Guidebook and abstracts of the IGCP-440 workshop, Irkutsk, pp 142-145

Kröner A, Windley BF, Badarch G, Tomurtogoo O, Hegner E, Jahn BM, GruschKa S, Khain EV, Demoux A, Wingate MTD (2007) Accretionary growth and crust formation in the Central Asian Orogenic Belt and comparison with the Arabian-Nubian Shield. In: HATCHER RD, Carlson MP, Mcbride JH, Martinez Catalan JR (eds) 4-D Framework of Continental Crust. Geological Society of America Memoirs 200: 181-209

Kröner A, Lehmann J, Schulmann K, Demoux A, Lexa O, Tomurhuu D, Štípská P, Liu D, Wingate MTD (2010) Lithostratigraphic and geochronological constraints on the evolution of the Central Asian Orogenic Belt in SW Mongolia: Early Paleozoic rifting followed by Late Paleozoic accretion. Amer J Sci 310: 523-574

Lehmann J, Schulmann K, Lexa O, Corsini M, Kröner A, ŠTíPSKÁ P, TomurhuU D, OtgONBATOR D (2010) Structural constraints on the evolution of the Central Asian Orogenic Belt in SW Mongolia. Amer J Sci 310: 575-628

Liew TC, Hofmann AW (1988) Precambrian crustal components, plutonic associations, plate environment of the Hercynian Fold Belt of central Europe: indicators from a Nd and Sm isotopic study. Contrib Mineral Petrol 98: 129-138

Lugmair GW, Marti K (1978) Lunar initial ${ }^{143} \mathrm{Nd} /{ }^{144} \mathrm{Nd}$ : differential evolution line of the lunar crust and mantle. Earth Planet Sci Lett 39: 349-357

Maniar PD, Piccoli PM (1989) Tectonic discrimination of granitoids. Geol Soc Am Bull 101: 635-643

Marinov NA, Zonenshain LP, Blagonravov VA (eds) (1973) Geology of Mongolian Republic. Nedra, Moscow, pp 1-782 (in Russian)

Markova NG (1975) Stratigraphy of lower and middle Paleozoic of Western Mongolia. Science, Moscow, pp 1-120 (in Russian)

Meldrum A, Boatner A, Ewing RC (1997) Displacive radiation effects in the monazite- and zircon-structure orthophosphates. Physics Reviews B 56: 13805-13814

Miall AD (1978) Lithofacies types and vertical profile models in braided river deposits: a summary. In: MIALL AD (ed) Fluvial Sedimentology. Canadian Society of Petroleum Geologists 5: 597-604

Miall AD (1996) The Geology of Fluvial Deposits: Sedimentary Facies, Basin Analysis and Petroleum Geology. Springer-Verlag, Berlin, pp 1-582
Mielke P, Winkler HGF (1979) Eine bessere Berechnung der Mesonorm für granitische Gesteine. Neu Jb Mineral, Mh 471-480

Montel JM, Foret S, Veschambre M, Nicollet C, Provost A (1996) Electron microprobe dating of monazite. Chem Geol 131: 37-53

Mossakovsky AA, Ruzhentsev SV, Samygin SG, KherasKOVA TN (1993) Central Asian Fold Belt: geodynamic evolution and history of formation. Geotectonics 6: 3-33

PARRISH RR (1990) U-Pb dating of monazite and its application to geological problems. Can J Earth Sci 27: 1432-1450

Pearce JA, Harris NBW, Tindle AG (1984) Trace element discrimination diagrams for the tectonic interpretation of granitic rocks. J Petrol 25: 956-983

Peccerillo R, TAylor SR (1976) Geochemistry of Eocene calc-alkaline volcanic rocks from the Kastamonu area, northern Turkey. Contrib Mineral Petrol 58: 63-81

Perfiliev AS, Kheraskov NN (1980) Diabase complexes and the origin of layering of Earth's crust: tectonic layering of the lithosphere. Nauka, Moscow, pp 64-104 (in Russian)

Pfänder J, Kröner A, Jochum KP, Kozakov IK, Oidup C (2000) Ocean crust formation and crustal accretion in south-central Asia: Neoproterozoic to Early Paleozoic ophiolite and island arc system in Tuva. In: BADARCH G, JAHN BM (eds) IGCP-420 Continental Growth in the Phanerozoic: Evidence from Central Asia. Abstract and Excursion Guidebook. Geosciences, Rennes, pp 63-64

Pouchou JL, Pichoir F (1985) "PAP“( $(\varphi \rho Z)$ procedure for improved quantitative microanalysis. In: ArMSTRONG JT (ed) Microbeam Analysis. San Francisco Press, pp 104-106

Ramos A, Sopeña A (1983) Gravel bars in low sinuosity streams (Permian and Triassic, central Spain). International Association of Sedimentology, Special Publications 6: 306-312

RauZer AA, Zhanchiv DI, Golyakov VI, Ykhina IF, Ivanov IG, Tsukernik AB, Afonin VV, SMirnov IG, ByKhover VI, Kravtsev AV, BaAtarkhuyag A, SKoryukin MI, Khodikov IV, Mantsev NV, OKaEmov SV, Mischin VA, ENKhSAJKhan $\mathrm{T}$ (1987) Report on results of geological survey at a scale of $1: 200,000$, performed in southeast part of the Mongolian Altay, Mongolian National Republic in 1983-1986. Tekhnoexport, Moscow, pp 1-352 (in Russian)

SENGÖR AMC, Natal'in BA, Burtman VS (1993) Evolution of the Altaid tectonic collage and Paleozoic crustal growth in Eurasia. Nature 364: 299-307

Schandl ES, GorTON MP (2002) Application of high field strength elements to discriminate tectonic settings in VMS environments. Econ Geol 97: 629-642

Shand SJ (1943) Eruptive Rocks, Their Genesis, Composition, Classification and Their Relation to the Ore-Deposits. $2^{\text {nd }}$ edition, J. Wiley and Sons, New York, pp 1-120 
Steiger RH, JÄGer E (1977) Subcommission on Geochronology; convention on the use of decay constants in geo- and cosmochronology. Earth Planet Sci Lett 36: $359-362$

Streckeisen A, Le Maitre RW (1979) A chemical approximation to the modal QAPF classification of the igneous rocks. Neu Jb Mineral, Abh 136: 169-206

Sun SS, McDonough WF (1989) Chemical and isotopic systematics of oceanic basalts: implications for mantle composition and processes. In: SAUNDERS AD, NorRy MJ (eds) Magmatism in Ocean Basins. Geological Society of London Special Publications 42: pp 313-345

Štípská P, Schulmann K, Lehmann J, Corsini M, Lexa O, Tomurhuu D (2010) Early Cambrian eclogites in SW Mongolia: evidence that the Paleo-Asian Ocean suture extends further east than expected. J Metamorphic Geol 28: 915-933

Tomurtogoo O (1997) A new tectonic scheme of the Paleozoides in Mongolia. Mongol Geosci 3: 12-17
VALtR V, HANŽL P (2008) Geophysical cross-section through the Bogd Fault System in the area of the Chandman Rupture, SW Mongolia. J Geosci 53: 193-200

Wilson M (1989) Igneous Petrogenesis. Harper Collins Academic, London, pp 1-466

Windley BF, Alexeiev D, Xiao W, Kröner A, Badarch G (2007) Tectonic models for the accretion of the Central Asian Orogenic Belt. J Geol Soc, London 164: 31-47

Yakubchuk A, Shatov VV, Kirwin D, Edwards A, Badarch G, BuryaK VA (2005) Gold and base metal metallogeny of the Central Asian orogenic supercollage. Econ Geol, $100^{\text {th }}$ Anniversary Volume: $1035-1068$

Yuan Ch, Sun M, Xiao W, Li X, Chen H, Lin S, Xia X, Long X (2007) Accretionary orogenesis of the Chinese Altai: insights from Paleozoic granitoids. Chem Geol 242: 22-39

Zonenshain LP, KuzMin MI (1978) The Khan-Taischir ophiolitic complex of Western Mongolia, its petrology, origin and comparison with other ophiolitic complexes. Contrib Mineral Petrol 67: 95-109 